Research Article

\title{
DFT Study for the Spectroscopic and Structural Analysis of p-Dimethylaminoazobenzene
}

\author{
Majid Ali, ${ }^{1}$ Asim Mansha $\left(\mathbb{D},{ }^{1}\right.$ Sadia Asim, ${ }^{2}$ Muhammad Zahid $\left(\mathbb{D},{ }^{3}\right.$ Muhammad Usman ${ }^{1},{ }^{1}$ \\ and Narmeen Ali \\ ${ }^{1}$ Department of Chemistry, Government College University Faisalabad, Faisalabad 38000, Pakistan \\ ${ }^{2}$ Department of Chemistry, Government College Women University, Faisalabad, Pakistan \\ ${ }^{3}$ Department of Chemistry, University of Agriculture Faisalabad, Faisalabad, Pakistan
}

Correspondence should be addressed to Asim Mansha; mansha.asim@gmail.com and Muhammad Zahid; rmzahid@uaf.edu.pk

Received 30 November 2017; Revised 24 February 2018; Accepted 18 March 2018; Published 5 April 2018

Academic Editor: Simona C. Pinzaru

Copyright (C) 2018 Majid Ali et al. This is an open access article distributed under the Creative Commons Attribution License, which permits unrestricted use, distribution, and reproduction in any medium, provided the original work is properly cited.

\begin{abstract}
The study under consideration represents the computational calculations of Azo-based direct dye named $p$ (dimethylamino)azobenzene (DMAB) under the effect of solvents with different relative permittivities. A density functional theory (DFT) method at the B3LYP level with 6-311G++ was applied for the spectroscopic and structural analysis of the title compound. Calculations of geometric parameters (bond orders, bond lengths, and dihedral angles), electron densities, thermodynamic parameters, and orbital energies were performed for the title compound. Mulliken population analysis (MPA) as well as natural population analysis (NPA) was also performed at the B3LYP level with different solvents for finding solvent effects. In order to predict the reactivity of DMAB, molecular electrostatic potential (MESP) calculations were carried out for it. For vibrational analysis, the infrared (IR) spectra were computed for the title compound at the B3LYP/6-311G++ level in the gas phase and in different solvents with good agreement to the experimental FT-IR spectrum. The different modes of vibrations were assigned using potential energy distribution (PED). The computed Raman spectra also showed appreciable agreement with the experimental recorded Raman spectrum. The electronic absorption spectra of the title compound have been computed employing DFT/B3LYP with the 6-311G++ basis set in the gas phase and in four different solvents, that is, DMSO, ethanol, acetonitrile, and water which were compared with the experimental spectra with appreciable agreement. NBO analysis was carried out for understanding the intramolecular and intermolecular bonding of the compound and the density transfer from completely filled to unfilled orbital was found. The HOMO-LUMO energies were determined for analyzing the mechanism of intramolecular charge transfer.
\end{abstract}

\section{Introduction}

The increasing interest in the azo compounds is due to their versatile properties which make them favorable for use in fiber dyeing, biological reactions (such as in tumor growth inhibition), and in analytical chemistry. Azo dyes are greatly important in the field of pigments, dyes, printing systems, optical storage, and advanced materials. More than 50\% colorants with the azo group are most widely employed in areas of dyeing such as that of textile fibers and in coloration of various materials. Their applications in advanced organic synthesis and biological and medical fields are well recognized [1-3]. Antibacterial activity of azo compounds and their metal chelates have also been reported [4]. The photosensitivity of azo dyes and their ability of bonding with $\mathrm{N}=\mathrm{N}$ groups [5] make them favorable for different applications. Brilliant color and chromophoric strength have been observed with aromatic azo dyes, especially known for their excellent sublimation fastness and light-based properties [6]. Their large color range, dyeing facility, and good stabilities make them highly demanding in industry. They are highly versatile for use in different fields and in technologies like chemosensing, nonlinear optics, and for optical data storage [7]. Azobenzenes are one of the most prominent classes of photo chromic molecules with two sis and trans isomers [8-11]. The introduction of multiple azobenzenes 


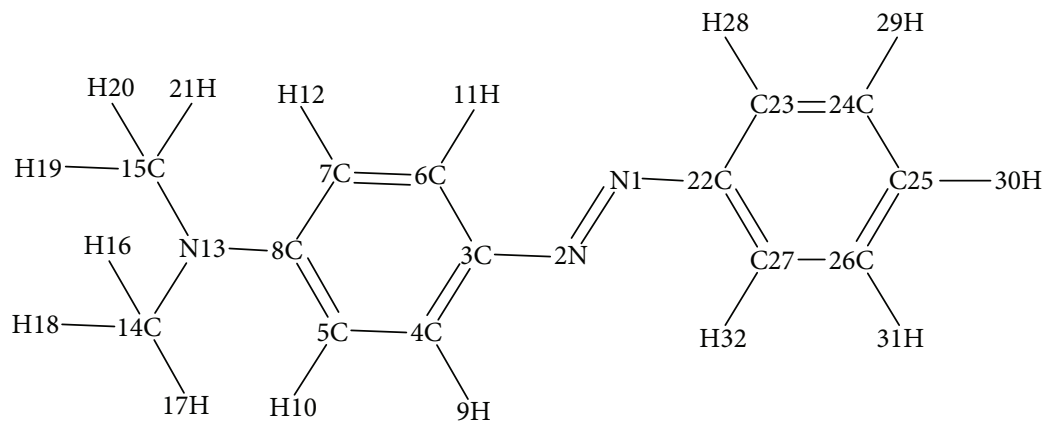

(a)

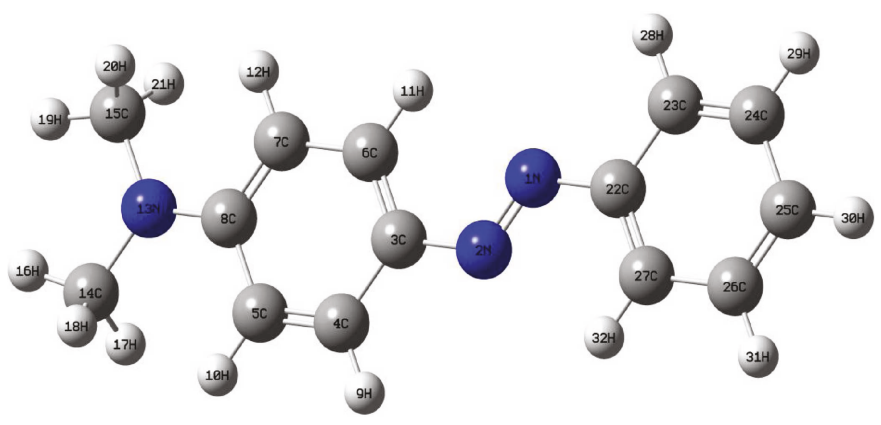

(b)

FIgure 1: (a). The normal structure of DMAB with atomic numbering. (b) The optimized structure of DMAB at DFT/B3LYP/6-311G++ in the gas phase.

in oligonucleotides assisted in regulation of DNA duplex formation [12]. The role of azobenzenes as convenient actinometers has also been reported [13].

In the present work, azo direct dye, named p-(dimethylamino)azobenzene (DMAB), was studied theoretically in the gas phase as well as in different solvents and its vibrational and structural properties have been reported in comparison with some experimental data. Multidisciplinary studies involving experimental as well as theoretical methods proved to be very useful for understanding the chemistry of the title compound and provide insight into molecular analysis $[14,15]$. This manuscript mainly deals with the structural and spectroscopic (IR, Raman, and UV-Vis absorption spectra) properties, $\mathrm{NBO}$ analysis, and transition states of the title compound and its behavior in different solvents. The energetic behavior has been examined in gas and different solvents (water, DMSO, ethanol, and acetonitrile).

\section{Materials and Methods}

2.1. Experimental Detail. The title compound, p-(dimethylamino)azobenzene (DMAB), was purchased from SigmaAldrich, having greater than $99 \%$ purity and no additional purification was made. An IFS 66V spectrophotometer using $\mathrm{KBr}$ pellets was employed for the recording of the FTIR spectrum in the $4000-400 \mathrm{~cm}^{-1}$ frequency range at room temperature. The scanning speed of $30 \mathrm{~cm}^{-1} \min ^{-1}$ was utilized with spectral resolution of $2.0 \mathrm{~cm}^{-1}$. The electronic absorption spectrum was recorded on the Hitachi U-2800 spectrophotometer [16]. The FRA 106 Raman module in the range of $3500-50 \mathrm{~cm}^{-1}$ was used for the recording of the FT-Raman spectrum.

2.2. Computational Details. Computational calculations were performed by employing the Gaussian 09 software [17]. The ground-state and excited-state geometries have been optimized in analytical gradients in Gaussian 09 using the DFT method in employing B3LYP correction with the 6-311G++ basis set [18]. The optimized parameters (bond length, bond angle, and dihedral angles) of DMAB have been obtained by using the same levels of theory [19]. The electronic spectrum of the compound is calculated in gas, water, and some other solvents (water, ethanol, DMSO, and acetonitrile) at DFT/ B3LYP/6-311G++. The minima of the potential energy hypersurfaces are considered to be the stationary points and were confirmed from the absence of any imaginary frequency. Moltran software was employed in computing thermodynamic parameters of DMAB [20]. The VEDA 4 program was used for the detailed vibrational analysis taking into account the computed potential energy distribution (PED). The computation of anharmonic frequencies for the fundamental vibrational modes with the corresponding IR intensities and the associated overtones was carried out [21]. A complete bond analysis was carried out using NBO analysis. The excitation energies and oscillator strengths for the lowest singlet-singlet transitions at the optimized geometry in the ground state were obtained as well by DFT calculations with the same basis set. Absorption spectra were 
TABLE 1: Optimized geometric parameters (bond lengths, bond angles, and selected dihedral angels) of DMAB at the DFT/B3LYP/6$311 \mathrm{G}++$ level and at MP2/6-311G++.

\begin{tabular}{|c|c|c|c|c|}
\hline Parameter & $\begin{array}{c}\text { MP2/6-311G++ } \\
\text { Gas }\end{array}$ & $\begin{array}{l}\text { B3LYP/6-311G++ } \\
\text { Gas }\end{array}$ & $\begin{array}{c}\text { B3LYP/6-311G++ } \\
\text { Water }\end{array}$ & $\begin{array}{c}\text { B3LYP/6-311G++ } \\
\text { Ethanol }\end{array}$ \\
\hline \multicolumn{5}{|c|}{ Bond length $(\AA)$} \\
\hline $\mathrm{N}_{1}-\mathrm{N}_{2}$ & 1.25 & 1.25 & 1.28 & 1.28 \\
\hline $\mathrm{N}_{1}-\mathrm{C}_{22}$ & 1.39 & 1.40 & 1.43 & 1.43 \\
\hline $\mathrm{N}_{2}-\mathrm{C}_{3}$ & 1.40 & 1.40 & 1.41 & 1.41 \\
\hline $\mathrm{C}_{3}-\mathrm{C}_{4}$ & 1.46 & 1.46 & 1.41 & 1.41 \\
\hline $\mathrm{C}_{3}-\mathrm{C}_{6}$ & 1.34 & 1.34 & 1.42 & 1.42 \\
\hline $\mathrm{C}_{4}-\mathrm{C}_{5}$ & 1.34 & 1.34 & 1.39 & 1.39 \\
\hline $\mathrm{C}_{4}-\mathrm{H}_{9}$ & 1.07 & 1.08 & 1.09 & 1.09 \\
\hline $\mathrm{C}_{5}-\mathrm{C}_{8}$ & 1.46 & 1.46 & 1.43 & 1.43 \\
\hline $\mathrm{C}_{5}-\mathrm{H}_{10}$ & 1.07 & 1.08 & 1.08 & 1.08 \\
\hline $\mathrm{C}_{6}-\mathrm{C}_{7}$ & 1.46 & 1.46 & 1.39 & 1.39 \\
\hline $\mathrm{C}_{6}-\mathrm{H}_{11}$ & 1.07 & 1.08 & 1.09 & 1.09 \\
\hline $\mathrm{C}_{7}-\mathrm{C}_{8}$ & 1.34 & 1.34 & 1.43 & 1.43 \\
\hline $\mathrm{C}_{7}-\mathrm{H}_{12}$ & 1.07 & 1.08 & 1.08 & 1.08 \\
\hline $\mathrm{C}_{8}-\mathrm{N}_{13}$ & 1.33 & 1.32 & 1.38 & 1.38 \\
\hline $\mathrm{N}_{13}-\mathrm{C}_{14}$ & 1.47 & 1.47 & 1.47 & 1.47 \\
\hline $\mathrm{N}_{13}-\mathrm{C}_{15}$ & 1.47 & 1.47 & 1.47 & 1.47 \\
\hline $\mathrm{C}_{14}-\mathrm{H}_{16}$ & 1.08 & 1.09 & 1.09 & 1.09 \\
\hline $\mathrm{C}_{14}-\mathrm{H}_{17}$ & 1.08 & 1.09 & 1.10 & 1.09 \\
\hline $\mathrm{C}_{14}-\mathrm{H}_{18}$ & 1.09 & 1.09 & 1.10 & 1.10 \\
\hline $\mathrm{C}_{15}-\mathrm{H}_{19}$ & 1.09 & 1.09 & 1.09 & 1.09 \\
\hline $\mathrm{C}_{15}-\mathrm{H}_{20}$ & 1.08 & 1.09 & 1.10 & 1.10 \\
\hline $\mathrm{C}_{15}-\mathrm{H}_{21}$ & 1.08 & 1.09 & 1.10 & 1.10 \\
\hline $\mathrm{C}_{22}-\mathrm{C}_{23}$ & 1.46 & 1.46 & 1.41 & 1.41 \\
\hline $\mathrm{C}_{22}-\mathrm{C}_{27}$ & 1.33 & 1.34 & 1.41 & 1.41 \\
\hline $\mathrm{C}_{23}-\mathrm{C}_{24}$ & 1.34 & 1.34 & 1.40 & 1.41 \\
\hline $\mathrm{C}_{23}-\mathrm{H}_{28}$ & 1.08 & 1.08 & 1.09 & 1.09 \\
\hline $\mathrm{C}_{24}-\mathrm{C}_{25}$ & 1.46 & 1.46 & 1.40 & 1.40 \\
\hline $\mathrm{C}_{24}-\mathrm{H}_{29}$ & 1.07 & 1.08 & 1.09 & 1.09 \\
\hline $\mathrm{C}_{25}-\mathrm{C}_{26}$ & 1.34 & 1.34 & 1.41 & 1.41 \\
\hline $\mathrm{C}_{25}-\mathrm{H}_{30}$ & 1.08 & 1.08 & 1.09 & 1.09 \\
\hline $\mathrm{C}_{26}-\mathrm{C}_{27}$ & 1.45 & 1.46 & 1.40 & 1.40 \\
\hline $\mathrm{C}_{26}-\mathrm{H}_{31}$ & 1.08 & 1.08 & 1.09 & 1.09 \\
\hline $\mathrm{C}_{27}-\mathrm{H}_{32}$ & 1.07 & 1.08 & 1.09 & 1.09 \\
\hline \multicolumn{5}{|l|}{ Bond angles $\left({ }^{\circ}\right)$} \\
\hline $\mathrm{N}_{2}-\mathrm{N}_{1}-\mathrm{C}_{22}$ & 199.9 & 120.0 & 116.2 & 116.2 \\
\hline $\mathrm{N}_{2}-\mathrm{C}_{3}-\mathrm{C}_{6}$ & 199.9 & 120.0 & 125.3 & 125.2 \\
\hline $\mathrm{C}_{4}-\mathrm{C}_{3}-\mathrm{C}_{6}$ & 120.0 & 120.0 & 118.4 & 118.5 \\
\hline $\mathrm{C}_{3}-\mathrm{C}_{4}-\mathrm{C}_{5}$ & 120.1 & 120.0 & 121.4 & 121.4 \\
\hline $\mathrm{C}_{4}-\mathrm{C}_{5}-\mathrm{H}_{10}$ & 120.0 & 120.0 & 118.7 & 118.7 \\
\hline $\mathrm{C}_{8}-\mathrm{C}_{5}-\mathrm{H}_{10}$ & 119.9 & 120.0 & 120.6 & 120.6 \\
\hline $\mathrm{C}_{3}-\mathrm{C}_{6}-\mathrm{H}_{11}$ & 120.0 & 120.0 & 119.6 & 119.5 \\
\hline $\mathrm{C}_{7}-\mathrm{C}_{6}-\mathrm{H}_{11}$ & 120.0 & 120.0 & 119.6 & 119.7 \\
\hline $\mathrm{C}_{6}-\mathrm{C}_{7}-\mathrm{C}_{8}$ & 120.0 & 120.0 & 121.1 & 121.1 \\
\hline $\mathrm{C}_{6}-\mathrm{C}_{7}-\mathrm{H}_{12}$ & 120.0 & 120.0 & 118.5 & 118.5 \\
\hline $\mathrm{C}_{5}-\mathrm{C}_{8}-\mathrm{C}_{7}$ & 119.9 & 120.0 & 117.6 & 117.6 \\
\hline $\mathrm{C}_{8}-\mathrm{N}_{13}-\mathrm{C}_{15}$ & 120.0 & 120.0 & 120.6 & 120.6 \\
\hline
\end{tabular}


TABLE 1: Continued.

\begin{tabular}{|c|c|c|c|c|}
\hline Parameter & $\begin{array}{c}\text { MP2/6-311G++ } \\
\text { Gas }\end{array}$ & $\begin{array}{c}\text { B3LYP/6-311G++ } \\
\text { Gas }\end{array}$ & $\begin{array}{c}\text { B3LYP/6-311G++ } \\
\text { Water }\end{array}$ & $\begin{array}{c}\text { B3LYP/6-311G++ } \\
\text { Ethanol }\end{array}$ \\
\hline $\mathrm{C}_{14}-\mathrm{N}_{13}-\mathrm{C}_{15}$ & 120.1 & 120.0 & 118.9 & 119.0 \\
\hline $\mathrm{N}_{13}-\mathrm{C}_{14}-\mathrm{H}_{16}$ & 109.4 & 109.5 & 109.0 & 109.0 \\
\hline $\mathrm{N}_{13}-\mathrm{C}_{14}-\mathrm{H}_{17}$ & 109.5 & 109.5 & 111.4 & 111.4 \\
\hline $\mathrm{N}_{13}-\mathrm{C}_{14}-\mathrm{H}_{18}$ & 109.5 & 109.5 & 111.4 & 111.4 \\
\hline $\mathrm{H}_{16}-\mathrm{C}_{14}-\mathrm{H}_{17}$ & 109.5 & 109.5 & 108.3 & 108.3 \\
\hline $\mathrm{H}_{16}-\mathrm{C}_{14}-\mathrm{H}_{18}$ & 109.5 & 109.5 & 108.3 & 108.3 \\
\hline $\mathrm{H}_{17}-\mathrm{C}_{14}-\mathrm{H}_{18}$ & 109.4 & 109.5 & 108.4 & 108.4 \\
\hline $\mathrm{N}_{13}-\mathrm{C}_{15}-\mathrm{H}_{19}$ & 109.6 & 109.5 & 109.0 & 109.0 \\
\hline $\mathrm{N}_{13}-\mathrm{C}_{15}-\mathrm{H}_{20}$ & 109.5 & 109.5 & 111.5 & 111.4 \\
\hline $\mathrm{N}_{13}-\mathrm{C}_{15}-\mathrm{H}_{21}$ & 109.4 & 109.5 & 111.4 & 111.5 \\
\hline $\mathrm{H}_{19}-\mathrm{C}_{15}-\mathrm{H}_{20}$ & 109.5 & 109.5 & 108.2 & 109.2 \\
\hline $\mathrm{H}_{19}-\mathrm{C}_{15}-\mathrm{H}_{21}$ & 109.5 & 109.5 & 108.2 & 108.2 \\
\hline $\mathrm{H}_{20}-\mathrm{C}_{15}-\mathrm{H}_{21}$ & 109.5 & 109.5 & 108.4 & 108.4 \\
\hline $\mathrm{N}_{1}-\mathrm{C}_{22}-\mathrm{C}_{23}$ & 119.9 & 120.0 & 115.5 & 115.5 \\
\hline $\mathrm{N}_{1}-\mathrm{C}_{22}-\mathrm{C}_{27}$ & 120.0 & 120.0 & 124.4 & 124.4 \\
\hline $\mathrm{C}_{24}-\mathrm{C}_{23}-\mathrm{H}_{28}$ & 120.0 & 120.0 & 121.0 & 121.0 \\
\hline $\mathrm{C}_{25}-\mathrm{C}_{24}-\mathrm{H}_{29}$ & 120.0 & 120.0 & 120.2 & 120.2 \\
\hline $\mathrm{C}_{24}-\mathrm{C}_{25}-\mathrm{C}_{26}$ & 119.9 & 120.0 & 119.8 & 119.8 \\
\hline $\mathrm{C}_{25}-\mathrm{C}_{26}-\mathrm{C}_{27}$ & 119.9 & 120.0 & 120.5 & 120.5 \\
\hline $\mathrm{C}_{27}-\mathrm{C}_{26}-\mathrm{H}_{31}$ & 120.0 & 120.0 & 119.6 & 119.6 \\
\hline $\mathrm{C}_{22}-\mathrm{C}_{27}-\mathrm{C}_{26}$ & 120.1 & 120.0 & 119.7 & 119.7 \\
\hline \multicolumn{5}{|l|}{ Dihedral angle $\left({ }^{\circ}\right)$} \\
\hline $\mathrm{C}_{22}-\mathrm{N}_{1}-\mathrm{N}_{2}-\mathrm{C}_{3}$ & 180.0 & 180.0 & 179.9 & 179.5 \\
\hline $\mathrm{N}_{2}-\mathrm{N}_{1}-\mathrm{C}_{22}-\mathrm{C}_{23}$ & 180.2 & 180.0 & 179.5 & 178.2 \\
\hline $\mathrm{N}_{2}-\mathrm{N}_{1}-\mathrm{C}_{22}-\mathrm{C}_{27}$ & 0.0 & 0.0 & 0.5 & 2.1 \\
\hline $\mathrm{N}_{1}-\mathrm{N}_{2}-\mathrm{C}_{3}-\mathrm{C}_{4}$ & 180.0 & 179.9 & 179.8 & 178.8 \\
\hline $\mathrm{N}_{2}-\mathrm{C}_{3}-\mathrm{C}_{6}-\mathrm{C}_{7}$ & 180.0 & 180.0 & 180.0 & 180.0 \\
\hline $\mathrm{N}_{2}-\mathrm{C}_{3}-\mathrm{C}_{6}-\mathrm{H}_{11}$ & 0.0 & 0.0 & 0.1 & 0.0 \\
\hline $\mathrm{C}_{3}-\mathrm{C}_{4}-\mathrm{C}_{5}-\mathrm{C}_{8}$ & 0.0 & 0.0 & 0.0 & 0.2 \\
\hline $\mathrm{C}_{3}-\mathrm{C}_{4}-\mathrm{C}_{5}-\mathrm{H}_{10}$ & 180.1 & 180.0 & 180.0 & 179.9 \\
\hline $\mathrm{C}_{4}-\mathrm{C}_{5}-\mathrm{C}_{8}-\mathrm{C}_{7}$ & 0.0 & 0.0 & 0.0 & 0.0 \\
\hline $\mathrm{C}_{4}-\mathrm{C}_{5}-\mathrm{C}_{8}-\mathrm{N}_{13}$ & 179.9 & 180 & 180.0 & 180.0 \\
\hline $\mathrm{H}_{10}-\mathrm{C}_{5}-\mathrm{C}_{8}-\mathrm{C}_{7}$ & 180.0 & 180.0 & 180.0 & 179.9 \\
\hline $\mathrm{H}_{10}-\mathrm{C}_{5}-\mathrm{C}_{8}-\mathrm{N}_{13}$ & 0.0 & 0.0 & 0.0 & 0.0 \\
\hline $\mathrm{C}_{8}-\mathrm{N}_{13}-\mathrm{C}_{14}-\mathrm{H}_{18}$ & 58.8 & 60.0 & 60.4 & 60.4 \\
\hline $\mathrm{C}_{15}-\mathrm{N}_{13}-\mathrm{C}_{14}-\mathrm{H}_{17}$ & 119.9 & 120.0 & 119.3 & 119.0 \\
\hline $\mathrm{C}_{8}-\mathrm{N}_{13}-\mathrm{C}_{15}-\mathrm{H}_{21}$ & 58.8 & 59.9 & 60.4 & 60.6 \\
\hline $\mathrm{C}_{14}-\mathrm{N}_{13}-\mathrm{C}_{15}-\mathrm{H}_{20}$ & 120.0 & 120.0 & 119.2 & 119.6 \\
\hline
\end{tabular}

taken with the same computational method. The spectral shifts obtained with different sets of samples were identical in most of the cases.

\section{Result and Discussion}

3.1. Structural Description. The compound under study is p-(dimethylamino)azobenzene. Molecular formula of the title compound is $\mathrm{C}_{14} \mathrm{H}_{15} \mathrm{~N}_{3}$. The preoptimized geometry at the Hartree-Fock level was used to obtain optimized geometry at DFT/B3LYP with the 6-311G++ basis set. The optimized structure with atom numbering is shown in Figure 1(b). The optimized structural parameters with DFT/B3LYP/6-311G++ in the gas phase MP2/6-311G++ results are listed in Table 1 . Geometric parameters were computed in various solvents (water and ethanol) which showed great accordance with the computed values at a higher level calculation of MP2/6-311G++. These optimized structures are helpful in computing a variety of parameters further. The optimized bond lengths of $\mathrm{C}_{14}-\mathrm{H}_{16}, \mathrm{C}_{14}-\mathrm{H}_{17}$, 
$\mathrm{C}_{14}-\mathrm{H}_{18}, \mathrm{C}_{15}-\mathrm{H}_{19}, \mathrm{C}_{15}-\mathrm{H}_{20}$, and $\mathrm{C}_{15}-\mathrm{H}_{20}$ are the same with the value of $1.09 \AA$. The dihedral angel between the $\left(\mathrm{C}_{22}-\mathrm{N}_{1}-\mathrm{N}_{2}-\mathrm{C}_{3}\right)$ of two rings of DMAB is $180^{\circ}$. Computed values of most of the bond lengths and bond angles have shown very close agreement with the MP2 level of calculations. The actual substance exist in the solid phase, hence weak Van der Waals interactions might be developed in molecule; therefore, small differences between computed and experimental parameters occur [22].

3.2. Vibrational Studies. DMAB is consisted of 32 atoms, and therefore, it shows 90 different modes of vibration. The IR spectra of DMAB computed at the DFT/B3LYP/6-311G++ level in different solvents including gas, water, DMSO, acetonitrile, and ethanol and scaled by 0.9688 [23] are given in Figure 2. A comparison of the calculated and observed IR spectra shows good agreement. Thus, more reliable assignment of IR active modes of vibration can be carried out by comparing experimental FTIR intensities with the computed wavenumbers. The computed (scaled) frequencies as well as the PEDs of selected vibrational modes of DMAB along with the experimentally observed FTIR/FT-Raman frequencies are listed in Table $2[24,25]$. The experimental and calculated scaled vibrational (IR) spectra are shown in Figure 2. In Figure 3, the computed Raman spectrum at the DFT/B3LYP/ $6-311 \mathrm{G}++$ level of theory scaled by 0.9688 [23] is compared with the recorded FT-Raman spectrum which reflect the good agreement.

The carbon-hydrogen symmetric stretching vibrations of the ring were observed in the frequency region of 3194, 3160, $3139,3112,3099,3065$, and $2997 \mathrm{~cm}^{-1}$. Generally, in the aromatic system, stretching vibrations of $\mathrm{C}-\mathrm{H}$ bond occur in the form of bands of variable intensity at $3073,3065,3020$, and $3017 \mathrm{~cm}^{-1}$ [25]. The $\mathrm{C}-\mathrm{C}$ aromatic stretching and $\mathrm{CCH}$ bending occur at 1575,1564 , and $1400 \mathrm{~cm}^{-1}$ [26]. The $\mathrm{C}=\mathrm{C}$ bond of aromatic system gave stretching vibrations in the region of $1695,1620,1607$, and $1566 \mathrm{~cm}^{-1}$. C-H in-plane bending was shown in the ranges of $1556,1553,1539,1525$, and $1485 \mathrm{~cm}^{-1}$ [27]. Asymmetric stretching vibration in C-C bond was exhibited at the frequency of $1356 \mathrm{~cm}^{-1}$. The sharp band in the region of 1146, 1335, and $1085 \mathrm{~cm}^{-1}$ is assigned as stretching vibration of CN bond. $\mathrm{CN}$ and $\mathrm{NN}$ bond stretching and bending in $\mathrm{NCH}$ fall in frequency ranges of 1092, 1085, 1078, 1057, and $1044 \mathrm{~cm}^{-1}$ [28]. Wagging of the $\mathrm{CH}_{3}$ group occurred at frequency of 963 and $936 \mathrm{~cm}^{-1}$. Out-of-plane bending in $\mathrm{CH}$ bond was appeared at 866 and $860 \mathrm{~cm}^{-1}$ [29]. The frequency ranges of $773,739,691$, and $671 \mathrm{~cm}^{-1}$ depicted the rocking and out-of-plane bending of the $\mathrm{CH}$ group. In-plane bending in CCC bond angle of aromatic ring was observed at frequency ranges of $630,563,549$, and $522 \mathrm{~cm}^{-1}$. In-plane bending in NCC bond angle was experienced at 522 and $461 \mathrm{~cm}^{-1}$ frequency ranges.

3.3. Natural Bond Orbital (NBO) Analysis. The basic objective of NBO analysis is to get chemical insight in the compound under discussion. Such insights are related to bonding concepts such as the Lewis structure and bonding type and atomic charges. Important NBO-computed

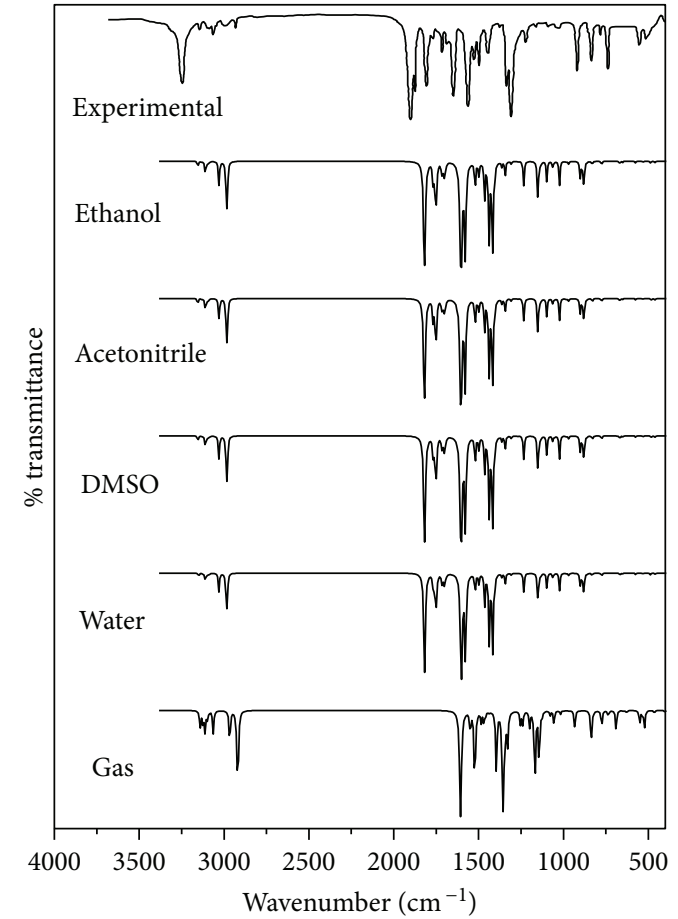

FIGURE 2: Computed (scaled) IR spectra of DMAB by DFT/6-311G ++ in different solvents with the experimental FTIR spectrum.

parameters exhibiting the formation of Lewis and nonLewis orbitals by valence hybrids are shown in Table 3. In order to estimate the donor-acceptor interaction, the second-order perturbation theory analysis of the Fock matrix was carried out. NBO analysis was performed on title molecule at the DFT/B3LYP/6-311G++ level in order to explain the rehybridization, intramolecular interactions, and delocalization of electron density within the molecule. The results of Fock matrix analysis are presented in Table 4 . The larger the $\mathrm{E}^{(2)}$ value, the stronger will be the interaction between electron donors and electron acceptors. The greater the donating tendency of electron donors, the greater will be the extent of conjugation of the whole system. The most prominent interactions in the gas phase of the title compound are due to interactions between donor $\mathrm{BD}\left(\mathrm{N}_{1}-\mathrm{N}_{2}\right)$ and acceptor $\mathrm{RY} *$ (C3), exhibiting the greatest interaction energies $\mathrm{E}^{(2)}$ value, that is, $4.1 \mathrm{kcal} / \mathrm{mol}$ [30].

The strong charge-transfer interaction through pconjugated bridge results in considerate mixing of ground-state donor and acceptor orbitals, and thus, the charge-transfer band appears in the electronic absorption spectrum. Resultantly, from the donor side of the pconjugated system, an electron density transfer is observed to its electron-withdrawing part [31].

3.4. Electronic Absorption Spectra. In order to understand the electronic transitions of DMAB, TD-SCF/DFT/B3LYP6$311 \mathrm{G}++$ calculations were used. The absorption spectra were recorded in gas and other solvents (water, DMSO, ethanol, and acetonitrile) which are represented in Figure 4 in comparison with the experimental one [32]. The maximum absorption in gas took place at $499.78 \mathrm{~nm}$, but the absorption 
TABLE 2: Comparison of experimental FTIR/FT-Raman and calculated (scaled) IR/Raman (gas) \& IR vibrational frequencies $\left(\mathrm{cm}^{-1}\right.$ ) of DMAB in different solvents employing DFT/B3LYP/6-311G++ with Raman activity and probable assignment (characterized by PED).

\begin{tabular}{|c|c|c|c|c|c|c|c|c|}
\hline \multirow{2}{*}{ Sr. number } & \multirow{2}{*}{$\begin{array}{l}\text { Experimental IR/Raman } \\
\text { wavenumber }\left(\mathrm{cm}^{-1}\right)\end{array}$} & \multicolumn{7}{|c|}{$\begin{array}{c}\text { Calculated wavenumbers }\left(\mathrm{cm}^{-1}\right) \\
\text { DFT/6-311G++ in }\end{array}$} \\
\hline & & $\mathrm{S}_{\text {Raman }}$ & Gas phase IR/Raman & Water & DMSO & Acetonitrile & Ethanol & $\begin{array}{l}\text { Vibrational } \\
\text { assignment }\end{array}$ \\
\hline 1 & 3256 & 6.50 & 3194.1 & & & & & $v_{\mathrm{CH}}(68)$ \\
\hline 2 & 3248 & 10.73 & 3160.2 & & & & & $v_{\mathrm{CH}}(45)$ \\
\hline 3 & 3146 & 3.11 & 3139.9 & & & & & $v_{\mathrm{CH}}(68)$ \\
\hline 4 & 3093 & 1.21 & 3112.8 & 3111.8 & 3119.5 & 3119.5 & 3119.5 & $v_{\mathrm{CH}}(33)$ \\
\hline 5 & 3085 & 9.98 & 3099.2 & & & & & $v_{\mathrm{CH} \text { sym }}(14)$ \\
\hline 6 & 3063 & 0.23 & 3065.3 & 3073.0 & 3073.0 & 3073.0 & 3073.0 & $v_{\mathrm{CH} \text { ar }}(14)$ \\
\hline 7 & 3000 & 5.76 & 2997.5 & & & & & $v_{\mathrm{CH}}(42), v_{\mathrm{CC}}(18)$ \\
\hline 8 & 2932 & 3.64 & 2970.3 & 2980.0 & 2980.0 & 2980.0 & 2980.0 & $v_{\text {CCanti sym }}(88)$ \\
\hline 9 & 1899 & 9.79 & 2963.6 & & & & & $v_{\mathrm{CC}}(26)$ \\
\hline 10 & 1872 & 0.12 & 2922.9 & 2925.8 & 2925.8 & 2925.8 & 2925.8 & $v_{\mathrm{CH} \text { ar }}(17)$ \\
\hline 11 & 1738 & 148.42 & 1695.4 & & & & & $v_{\mathrm{CC}}(23)$ \\
\hline 12 & 1717 & 8.98 & 1620.8 & & & & & $v_{\mathrm{CC} \text { sym }}(19)$ \\
\hline 13 & 1689 & 4.80 & 1607.2 & 1592.7 & 1592.7 & 1592.7 & 1592.7 & $v_{\mathrm{CC}}(12), v_{\mathrm{CH}}(11)$ \\
\hline 14 & 1647 & 12.03 & 1600.5 & & & & & $v_{\mathrm{CC} \text { ar }}(19)$ \\
\hline 15 & 1564 & 11.31 & 1566.5 & & & & & $v_{\mathrm{CC} \mathrm{ar}}(11), \delta_{\mathrm{CCH}}(17)$ \\
\hline 16 & & 3.58 & 1553.0 & & & & & $v_{\mathrm{CC}}(10), \delta_{\mathrm{CCH}}(11)$ \\
\hline 17 & 1529 & 17.79 & 1539.4 & & & & & $v_{\mathrm{CC}}(13), v_{\mathrm{CH}}(11)$ \\
\hline 18 & 1514 & 4.92 & 1525.9 & 1515.2 & 1515.2 & 1515.2 & 1515.2 & $\beta_{\mathrm{CH}}(22)$ \\
\hline 19 & 1497 & 197.51 & 1485.2 & 1461.0 & 1461.0 & 1461.0 & 1461.0 & $\beta_{\mathrm{CH}}(26), \delta_{\mathrm{HCC}}(29)$ \\
\hline 20 & 1458 & 256.08 & 1478.4 & & & & & $\beta_{\mathrm{CH}}(21), v_{\mathrm{CC}}(33)$ \\
\hline 21 & 1440 & 97.58 & 1437.7 & & & & & $\begin{array}{c}v_{\mathrm{CC}}(13), \delta_{\mathrm{HCC}}(11) \\
\delta_{\mathrm{CCC}}(37)\end{array}$ \\
\hline 22 & & 246.89 & 1430.9 & & & & & $\beta_{\mathrm{CH}}(18)$ \\
\hline 23 & & 4.45 & 1397.0 & & & & & $\begin{array}{c}v_{\mathrm{CH}}(22), \delta_{\mathrm{HCC}}(10) \\
\delta_{\mathrm{CCC}}(18)\end{array}$ \\
\hline 24 & 1377 & 4.58 & 1363.1 & & & & & $v_{\mathrm{CC}}(55)$ \\
\hline 25 & & 2.47 & 1356.3 & 1344.7 & 1344.7 & 1352.4 & 1344.7 & $v_{\mathrm{CC}}(26)$ \\
\hline 26 & 1336 & 4.88 & 1336.0 & & & & & $\beta_{\mathrm{CH}}(22), v_{\mathrm{CC}}(13)$ \\
\hline 27 & & 2.27 & 1329.2 & 1321.4 & 1321.4 & 1321.4 & 1321.4 & $v_{\mathrm{CC}}(16)$ \\
\hline 28 & 1314 & 3.30 & 1315.6 & & & & & $\delta_{\mathrm{HCC}}(21), v_{\mathrm{CC}}(13)$ \\
\hline 29 & 1309 & 19.69 & 1274.9 & & & & & $v_{\mathrm{CC}}(40)$ \\
\hline 30 & 1223 & 169.30 & 1241.0 & 1251.7 & 1251.7 & 1251.7 & 1251.7 & $\begin{array}{c}\beta_{\mathrm{CH}}(24), v_{\mathrm{CC}}(12) \\
\delta_{\mathrm{CCC}}(10)\end{array}$ \\
\hline 31 & & 7.95 & 1200.3 & 1228.4 & 1228.4 & 1228.4 & 1228.4 & $\beta_{\mathrm{CH}}(22), v_{\mathrm{CC} \text { ar }}(28)$ \\
\hline 32 & & 19.53 & 1193.6 & & & & & $v_{\text {CCanti sym }}(21), \beta_{\mathrm{CH}}$ \\
\hline 33 & 1160 & 1.38 & 1166.4 & 1189.7 & 1189.7 & 1189.7 & 1189.7 & $\begin{array}{c}\beta_{\mathrm{HCCH}}(11), \gamma_{\mathrm{HCC}} \\
(48), v_{\mathrm{CC}}(13)\end{array}$ \\
\hline 34 & & 1.23 & 1146.1 & 1158.7 & 1158.7 & 1158.7 & 1158.7 & $\begin{array}{c}v_{\mathrm{CN}}(22), v_{\mathrm{NN}}(41) \\
\delta_{\mathrm{NCH}}(10)\end{array}$ \\
\hline 35 & 1132 & 0.69 & & 1135.4 & 1135.4 & 1135.4 & 1135.4 & $\begin{array}{c}v_{\mathrm{CN}}(24), v_{\mathrm{NN}}(31) \\
\delta_{\mathrm{NCH}}(16)\end{array}$ \\
\hline 36 & 1090 & 3.11 & 1085.1 & & & & & $v_{\mathrm{CN}}(19), \gamma_{\mathrm{CCC}}(21)$ \\
\hline 37 & 1072 & 1.02 & 1078.3 & 1073.4 & 1073.4 & 1073.4 & 1073.4 & $\begin{array}{c}v_{\mathrm{CN}}(16), \delta_{\mathrm{NCH}}(12) \\
\delta_{\mathrm{HCC}}(10)\end{array}$ \\
\hline 38 & 1033 & 4.36 & 1057.9 & 1050.2 & 1050.2 & 1050.2 & 1050.2 & $v_{\mathrm{CN}}(16), \gamma_{\mathrm{HCC}}(20)$ \\
\hline 39 & & 13.73 & 1051.1 & & & & & $\gamma_{\mathrm{CCC}}(23)$ \\
\hline
\end{tabular}


TABLE 2: Continued.

\begin{tabular}{|c|c|c|c|c|c|c|c|c|}
\hline \multirow{2}{*}{ Sr. number } & \multirow{2}{*}{$\begin{array}{l}\text { Experimental IR/Raman } \\
\text { wavenumber }\left(\mathrm{cm}^{-1}\right)\end{array}$} & \multicolumn{7}{|c|}{$\begin{array}{c}\text { Calculated wavenumbers }\left(\mathrm{cm}^{-1}\right) \\
\text { DFT/6-311G++ in }\end{array}$} \\
\hline & & $S_{\text {Raman }}$ & Gas phase IR/Raman & Water & DMSO & Acetonitrile & Ethanol & $\begin{array}{l}\text { Vibrational } \\
\text { assignment }\end{array}$ \\
\hline 40 & & 0.23 & 1017.2 & 1011.4 & 1011.4 & 1011.4 & 1011.4 & $\begin{array}{c}\tau_{\mathrm{HCCC}}(68), \tau_{\mathrm{CCCC}} \\
(13)\end{array}$ \\
\hline 41 & & 3.16 & 963.0 & & & & & $\tau_{\mathrm{CCCC}}(18), v_{\mathrm{CC}}(12)$ \\
\hline 42 & 917 & 0.11 & 935.9 & 926.2 & 926.2 & 926.2 & 926.2 & $\Omega_{\mathrm{HCC}}(51)$ \\
\hline 43 & & 1.15 & 861.3 & & & & & $\gamma_{\mathrm{CCC}}(48), \delta_{\mathrm{HCC}}(11)$ \\
\hline 44 & 839 & 0.08 & 834.1 & 833.2 & 833.2 & 833.2 & 833.2 & $\begin{array}{c}\gamma_{\mathrm{CCC}}(26), \omega_{\mathrm{HCC}}(12), \\
\tau_{\mathrm{HCCC}}(48)\end{array}$ \\
\hline 45 & 782 & 2.35 & 773.1 & 771.2 & 771.2 & 771.2 & 771.2 & $\tau_{\mathrm{HCCC}}(28), \gamma_{\mathrm{CCC}}(33)$ \\
\hline 46 & 734 & 0.06 & 739.2 & 732.4 & 732.4 & 732.4 & 732.4 & $\gamma_{\mathrm{CCC}}(47), v_{\mathrm{CC}}(17)$ \\
\hline 47 & & 0.79 & 691.7 & 685.9 & 685.9 & 685.9 & 685.9 & $\delta_{\mathrm{CCC}}(10), \gamma_{\mathrm{CCC}}(11)$ \\
\hline 48 & & 1.21 & 671.4 & & & & & $\gamma_{\mathrm{CCC}}(19), \tau_{\mathrm{CCCC}}(17)$ \\
\hline 49 & & 0.03 & 630.7 & 623.9 & 623.9 & 623.9 & 623.9 & $\gamma_{\mathrm{CCC}}(11), \tau_{\mathrm{CCCC}}(12)$ \\
\hline 50 & & 1.24 & 562.9 & & & & & $\gamma_{\mathrm{CCC}}(36)$ \\
\hline 51 & 552 & 0.10 & 549.3 & 546.4 & 546.4 & 546.4 & 546.4 & $\delta_{\mathrm{NCC}}(22), \gamma_{\mathrm{HCC}}(14)$ \\
\hline 52 & 515 & 0.03 & 522.2 & 523.2 & 523.2 & 523.2 & 523.2 & $\begin{array}{c}\delta_{\mathrm{CN}}(56), \delta_{\mathrm{NCC}}(16) \\
\omega_{\mathrm{HCC}}(10)\end{array}$ \\
\hline 53 & & 0.09 & 461.1 & 468.9 & 461.1 & 461.1 & 461.1 & $\delta_{\mathrm{CN}}(33), \tau_{\mathrm{CCCC}}(21)$ \\
\hline 54 & & 0.01 & 271.3 & 275.1 & 275.1 & 282.9 & 282.9 & $\tau_{\mathrm{CCCC}}(26)$ \\
\hline 55 & & 0.00 & 176.3 & 174.4 & 174.4 & 174.4 & 174.4 & $\omega_{\mathrm{CCCC}}(33), \tau_{\mathrm{CCCC}}$ \\
\hline 56 & & 0.02 & 122.1 & 120.1 & 120.1 & 120.1 & 120.1 & $\omega_{\mathrm{CCCC}}(29)$ \\
\hline 57 & & 0.00 & 61.0 & 73.6 & 65.9 & 65.9 & 73.6 & $\gamma_{\mathrm{CCC}}(46)$ \\
\hline 58 & & 4.93 & 40.7 & 42.6 & 42.6 & 42.6 & 42.6 & $\omega_{\mathrm{CCCC}}(27)$ \\
\hline
\end{tabular}

Abbreviations: $v$ : stretching; $\gamma$ : bending; $\delta$ : rocking; $\tau$ : torsion; $\beta$ : scissoring; $\omega$ : waging; sym: symmetric; anti sym: anti-symmetric; ar: aromatic.

peaks in all other solvents exhibited small variations than in gas possibly due to the solvent effect. The UV absorption was found to be much stronger than that in the visible region. It was found that the calculated line shape and relative strengths of peaks are in good agreement with those of the experimental results [33]. Table 5 shows the calculated and experimental wavelengths from absorption, \% contribution from each transition, transition energies, and oscillator strength computed at the B3LYP/6-311G++ level for DMAB in gas and different solvents (DMSO, ethanol, acetonitrile, and water).

3.5. HOMO-LUMO Energy and Thermodynamic Parameter Studies. The HOMO and LUMO orbitals computed at the B3LYP6-311G++ level are shown in Figure 5. Their energy gaps were observed to be the lowest-energy transitions as depicted in Table 6 . The difference of energy between HOMO (the highest occupied molecular orbital) and LUMO (lowest unoccupied molecular orbital) was determined to elucidate excitation energy [34] and was calculated by equation,

$$
\Delta \mathrm{E}=\mathrm{E}_{\text {HOMO }}-\mathrm{E}_{\text {LUMO }} .
$$

In a reaction, these orbitals (HOMO and LUMO) act as the main chemical participants. The HOMO orbital is an electron donor, on the other hand, LUMO has the capacity

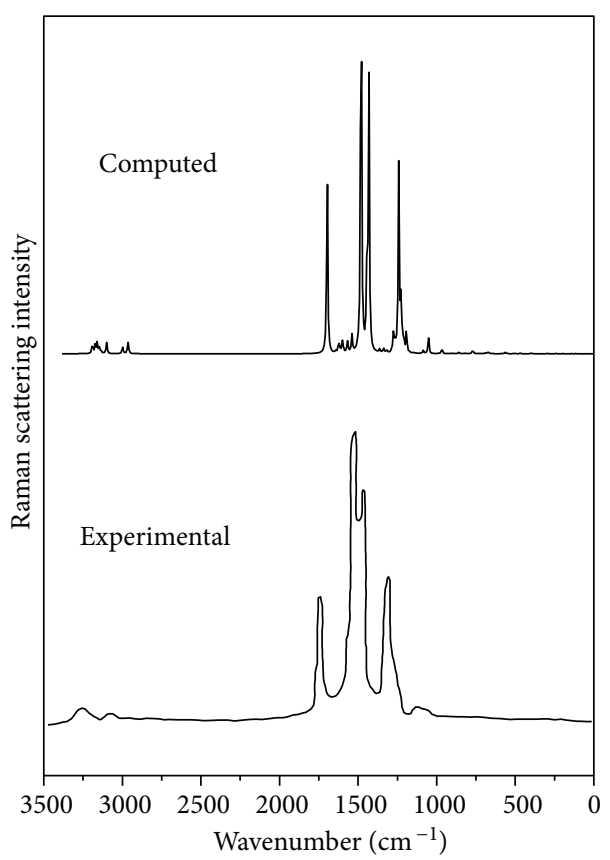

FIgURe 3: The experimental FT-Raman spectrum of DMAB and the computed (scaled) Raman spectrum of DMAB by DFT/B3LYP/6$311 \mathrm{G}++$. 
TABLE 3: Selected NBO results exhibiting the formation of Lewis and non-Lewis orbitals by valence hybrids at DFT/6-311G++ in gas.

\begin{tabular}{|c|c|c|c|c|c|c|}
\hline Bond & Occupancy & $\mathrm{ED}_{\mathrm{A}}(\%)$ & $\mathrm{ED}_{\mathrm{B}}(\%)$ & NBO \% & S (\%) & $\mathrm{P}(\%)$ \\
\hline $\mathrm{BD} \mathrm{N}_{1}-\mathrm{N}_{2}$ & 1.98648 & 49.94 & 50.06 & $0.7067 \mathrm{sp}^{2.11}+0.7075 \mathrm{sp}^{2.11}$ & $32.18,32.14$ & $67.82,67.86$ \\
\hline $\mathrm{BD} * \mathrm{~N}_{1}-\mathrm{N}_{2}$ & 0.00831 & 50.06 & 49.94 & $0.7075 \mathrm{sp}^{2.11}-0.7067 \mathrm{sp}^{2.11}$ & $32.18,32.14$ & $67.82,67.86$ \\
\hline $\mathrm{BD} \mathrm{N}_{1}-\mathrm{C}_{22}$ & 1.98166 & 58.81 & 41.81 & $0.7686 \mathrm{sp}^{1.84}+0.6418 \mathrm{sp}^{2.56}$ & $35.19,28.05$ & $64.81,71.95$ \\
\hline $\mathrm{BD} * \mathrm{~N}_{1}-\mathrm{C}_{22}$ & 0.03129 & 41.19 & 58.81 & $0.6418 s p^{1.84}-0.7668 \mathrm{sp}^{2.56}$ & $35.19,28.05$ & $64.81,71.95$ \\
\hline $\mathrm{BD} \mathrm{C}_{3}-\mathrm{C}_{4}$ & 1.97307 & 50.96 & 49.04 & $0.7139 \mathrm{sp}^{1.92}+0.7003 \mathrm{sp}^{2.1}$ & $34.27,32.25$ & $65.73,67.75$ \\
\hline $\mathrm{BD} * \mathrm{C}_{3}-\mathrm{C}_{4}$ & 0.02745 & 49.04 & 50.96 & $0.7003 \mathrm{sp}^{1.92}-0.7139 \mathrm{sp}^{2.1}$ & $34.27,32.25$ & $65.73,67.75$ \\
\hline $\mathrm{BD} \mathrm{C}_{5}-\mathrm{H}_{10}$ & 1.97812 & 62.39 & 37.61 & $0.7899 \mathrm{sp}^{2.25}+0.6133 \mathrm{~s}$ & $30.75,100$ & 69.25 \\
\hline $\mathrm{BD} * \mathrm{C}_{5}-\mathrm{H}_{10}$ & 0.01276 & 37.61 & 62.39 & $0.6133 \mathrm{sp}^{2.25}-0.7899 \mathrm{~s}$ & $30.75,100$ & 59.25 \\
\hline $\mathrm{BD} \mathrm{N}_{13}-\mathrm{C}_{15}$ & 1.9878 & 62.86 & 37.14 & $0.7929 \mathrm{sp}^{2.23}+0.6094 \mathrm{sp}^{3.7}$ & $30.91,21.21$ & $69.09,78.79$ \\
\hline $\mathrm{BD} * \mathrm{~N}_{13}-\mathrm{C}_{15}$ & 0.01762 & 37.14 & 62.86 & $0.6494 \mathrm{sp}^{2.23}-0.7929 \mathrm{sp}^{3.7}$ & $30.91,21.21$ & $69.09,78.79$ \\
\hline $\mathrm{BD} \mathrm{C}_{15}-\mathrm{H}_{20}$ & 1.98968 & 62.54 & 37.46 & $0.7908 \mathrm{sp}^{2.81}+0.6121 \mathrm{~s}$ & $26.26,100$ & 73.74 \\
\hline $\mathrm{BD} * \mathrm{C}_{15}-\mathrm{H}_{20}$ & 0.01624 & 37.46 & 62.54 & $0.6121 \mathrm{sp}^{2.81}-0.7908 \mathrm{~s}$ & $26.26,100$ & 73.74 \\
\hline $\mathrm{BD} \mathrm{C}_{27}-\mathrm{H}_{32}$ & 1.97779 & 63.68 & 36.32 & $0.798 \mathrm{sp}^{2.2}+0.6026 \mathrm{~s}$ & $31.24,100$ & 68.76 \\
\hline $\mathrm{BD} * \mathrm{C}_{27}-\mathrm{H}_{32}$ & 0.01848 & 36.32 & 63.68 & $0.6026 \mathrm{sp}^{2.2}-0.7980 \mathrm{~s}$ & $31.24,100$ & 68.76 \\
\hline
\end{tabular}

TABLE 4: Selected second-order perturbation theory analysis of the Fock matrix responsible for the most important donor-acceptor interactions for DMAB by a DFT/6-311G++ method in gas.

\begin{tabular}{|c|c|c|c|c|c|}
\hline $\begin{array}{l}\text { Sr. } \\
\text { number }\end{array}$ & $\begin{array}{c}\text { Donor } \\
\text { NBO (i) }\end{array}$ & $\begin{array}{l}\text { Acceptor } \\
\text { NBO (j) }\end{array}$ & $\begin{array}{c}\mathrm{E}^{(2)}(\mathrm{kcal} / \\
\mathrm{mol})\end{array}$ & $\begin{array}{c}\mathrm{E}(\mathrm{j})-\mathrm{E}(\mathrm{i}) \\
\text { (a.u.) }\end{array}$ & $\begin{array}{l}\mathrm{F}_{(\mathrm{i}, \mathrm{j})} \\
\text { (a.u.) }\end{array}$ \\
\hline 1 & $\mathrm{BD} \mathrm{N} \mathrm{N}_{1}-\mathrm{N}_{2}$ & $\mathrm{RY} * \mathrm{C}_{3}$ & 4.1 & 1.97 & 0.08 \\
\hline 2 & BD N $\mathrm{N}_{1}-\mathrm{C}_{22}$ & $\mathrm{RY} * \mathrm{~N}_{2}$ & 0.89 & 1.55 & 0.033 \\
\hline 3 & $\mathrm{BD} \mathrm{N}_{2}-\mathrm{C}_{3}$ & $\mathrm{RY} * \mathrm{C}_{4}$ & 0.69 & 1.92 & 0.033 \\
\hline 4 & $\mathrm{BD} \mathrm{C}_{3}-\mathrm{C}_{4}$ & $\mathrm{RY} * \mathrm{~N}_{2}$ & 0.7 & 1.65 & 0.031 \\
\hline 5 & $\mathrm{BD} \mathrm{C}_{5}-\mathrm{C}_{8}$ & $\begin{array}{c}\mathrm{BD} * \\
\mathrm{~N}_{13}-\mathrm{C}_{15}\end{array}$ & 4.81 & 0.96 & 0.061 \\
\hline 6 & $\mathrm{BD} \mathrm{C}_{5}-\mathrm{H}_{10}$ & $\mathrm{RY} * \mathrm{C}_{4}$ & 1.09 & 1.67 & 0.038 \\
\hline 7 & $\mathrm{BD} \mathrm{C}_{6}-\mathrm{H}_{11}$ & $\begin{array}{c}\mathrm{BD} * \mathrm{C}_{7^{-}} \\
\mathrm{C}_{8}\end{array}$ & 2.69 & 1.17 & 0.05 \\
\hline 8 & $\mathrm{BD} \mathrm{C}_{7}-\mathrm{C}_{8}$ & $\mathrm{RY} * \mathrm{C}_{5}$ & 0.56 & 1.56 & 0.027 \\
\hline 9 & $\mathrm{BD} \mathrm{C}_{27}-\mathrm{H}_{32}$ & $\begin{array}{c}\mathrm{BD} * \\
\mathrm{C}_{25}-\mathrm{C}_{26}\end{array}$ & 2.62 & 1.17 & 0.049 \\
\hline 10 & $\mathrm{CR} \mathrm{N}_{1}$ & $\mathrm{RY} * \mathrm{~N}_{2}$ & 1.82 & 15.18 & 0.149 \\
\hline 11 & $\mathrm{CR} \mathrm{C}_{8}$ & $\begin{array}{c}\mathrm{BD} * \\
\mathrm{~N}_{13}-\mathrm{C}_{15}\end{array}$ & 1.14 & 10.37 & 0.097 \\
\hline 12 & $\mathrm{CR} \mathrm{N}_{13}$ & $\mathrm{RY} * \mathrm{C}_{8}$ & 2.7 & 15.09 & 0.18 \\
\hline 13 & $\mathrm{LP} \mathrm{N}_{13}$ & $\begin{array}{c}\mathrm{BD} * \\
\mathrm{C}_{15}-\mathrm{H}_{21}\end{array}$ & 4.83 & 0.67 & 0.055 \\
\hline 14 & $\begin{array}{c}\mathrm{BD} * \mathrm{~N}_{1}- \\
\mathrm{N}_{2}\end{array}$ & $\mathrm{RY} * \mathrm{~N}_{1}$ & 1.06 & 0.81 & 0.074 \\
\hline
\end{tabular}

$\mathrm{E}^{(2)}$ means stabilization energy; $\mathrm{E}(\mathrm{j})$ - $\mathrm{E}(\mathrm{i})$ is energy difference between donor and acceptor $i$ and $j$ NBO Orbitals; $F(i, j)$ is the Fock matrix element between $i$ and $\mathrm{j}$ NBO orbitals.

to act as an acceptor, and their energy gap predicts the reactivity as well as chemical stability of the compound. The lower energy gap between the orbitals indicates high reactivity and low stability of the compound [35]. Most probable electronic transition is from $\pi-\pi *$. Slight variations in HOMO-LUMO energy gaps of all the solvents are shown in

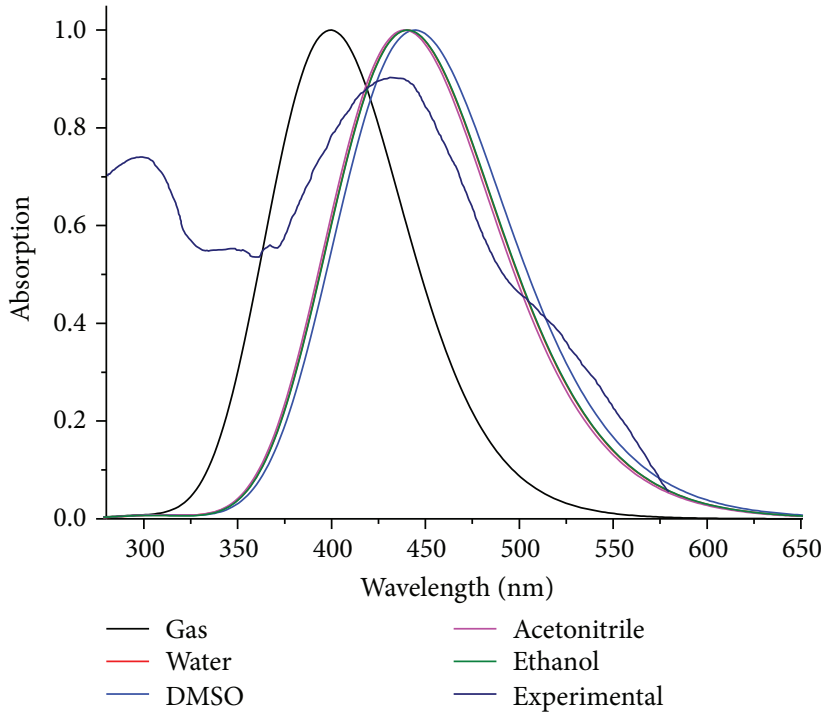

FIgURE 4: UV-Vis spectra of DMAB recorded by B3LYP/6-311G++ in different media with the experimental spectrum.

Table 6 along with some thermodynamic parameters like thermal correction to enthalpy (Hcorr) and thermal correction to Gibbs free energy (Gcorr).

Thermodynamic functions including internal energy, enthalpy, entropy, Gibbs free energy, and heat capacity for $\mathrm{DMAB}$ in the gas phase in a temperature range of 0 to $500 \mathrm{~K}$ are presented in Figure 6. The parameters were calculated using Moltran software. Thermodynamic parameters were found to be varied with varying temperature. The computed values of entropy were observed to increase with the increasing temperature [36]. Different thermodynamic parameters like enthalpy, Gibbs free energy, and entropy are used to describe the state as well as direction of a chemical reaction. These parameters also examine the spontaneity of a reaction, its energy profile, that is, either endothermic or 
TABLE 5: Calculated and experimental electronic transition parameters of the DMAB by a B3LYP/6-311G++ method in gas and other solvents.

\begin{tabular}{|c|c|c|c|c|c|}
\hline \multirow{2}{*}{ Media } & \multirow{2}{*}{ Transitions with \% contributions } & \multicolumn{2}{|c|}{ Wavelength (nm) } & \multirow{2}{*}{ Oscillator strength (f) } & \multirow{2}{*}{ Energy $(\mathrm{eV})$} \\
\hline & & Computed & Experimental & & \\
\hline \multirow[b]{3}{*}{ Gas } & $\begin{array}{l}\text { Excited state } 1 \\
\mathrm{H}-1 \rightarrow \mathrm{L}(65.9)\end{array}$ & 499.8 & & 0 & 2.4808 \\
\hline & $\begin{array}{c}\text { Excited state } 2 \\
\mathrm{H} \rightarrow \mathrm{L}(62.6)\end{array}$ & 399.5 & & 0.9213 & 3.1037 \\
\hline & $\begin{array}{c}\text { Excited state } 3 \\
\mathrm{H}-3 \rightarrow \mathrm{L}(61.2) \\
\mathrm{H}-2 \rightarrow \mathrm{L}(21.7) \\
\mathrm{H}-2 \rightarrow \mathrm{L}+3(12.5) \\
\mathrm{H} \rightarrow \mathrm{L}+1(10.5) \\
\mathrm{H} \rightarrow \mathrm{L}+3(19.7)\end{array}$ & 299.5 & & 0.0063 & 4.1401 \\
\hline \multirow[b]{3}{*}{ Water } & $\begin{array}{l}\text { Excited state } 1 \\
\mathrm{H}-1 \rightarrow \mathrm{L}(66.3)\end{array}$ & 481.7 & 538 & 0.0003 & 2.5741 \\
\hline & $\begin{array}{c}\text { Excited state } 2 \\
\mathrm{H} \rightarrow \mathrm{L}(62.5)\end{array}$ & 440.2 & 437 & 1.0712 & 2.8167 \\
\hline & $\begin{array}{c}\text { Excited state } 3 \\
\mathrm{H}-3 \rightarrow \mathrm{L}(61.0) \\
\mathrm{H}-2 \rightarrow \mathrm{L}(24.1) \\
\mathrm{H} \rightarrow \mathrm{L}+1(16.2) \\
\mathrm{H} \rightarrow \mathrm{L}+2(13.4)\end{array}$ & 307.4 & 301 & 0.0081 & 4.0329 \\
\hline \multirow[b]{3}{*}{ DMSO } & $\begin{array}{l}\text { Excited state } 1 \\
\mathrm{H}-1 \rightarrow \mathrm{L}(66.0)\end{array}$ & 485.3 & 540 & 0.0049 & 2.5548 \\
\hline & $\begin{array}{c}\text { Excited state } 2 \\
\mathrm{H} \rightarrow \mathrm{L}(62.8)\end{array}$ & 444.2 & 441 & 1.093 & 2.7911 \\
\hline & $\begin{array}{c}\text { Excited state } 3 \\
\mathrm{H}-3 \rightarrow \mathrm{L}(61.0) \\
\mathrm{H}-2 \rightarrow \mathrm{L}(24.3) \\
\mathrm{H} \rightarrow \mathrm{L}+1(15.9) \\
\mathrm{H} \rightarrow \mathrm{L}+2(13.6)\end{array}$ & 307.0 & 303 & 0.0089 & 4.0388 \\
\hline \multirow[b]{3}{*}{ Acetonitrile } & $\begin{array}{c}\text { Excited state } 1 \\
\mathrm{H}-1 \rightarrow \mathrm{L}(66.28)\end{array}$ & 485.4 & 539 & 0 & 2.5544 \\
\hline & $\begin{array}{l}\text { Excited state } 2 \\
\mathrm{H} \rightarrow \mathrm{L}(62.79)\end{array}$ & 438.9 & 440 & 1.0697 & 2.8249 \\
\hline & $\begin{array}{c}\text { Excited state } 3 \\
\mathrm{H}-3 \rightarrow \mathrm{L}(61.2) \\
\mathrm{H}-2 \rightarrow \mathrm{L}(23.4) \\
\mathrm{H} \rightarrow \mathrm{L}+1(16.2) \\
\mathrm{H} \rightarrow \mathrm{L}+2(14.0)\end{array}$ & 305.6 & 301 & 0.0087 & 4.0565 \\
\hline \multirow[b]{3}{*}{ Ethanol } & $\begin{array}{l}\text { Excited state } 1 \\
\mathrm{H}-1 \rightarrow \mathrm{L}(70.5)\end{array}$ & 480.9 & 536 & 0 & 2.5779 \\
\hline & $\begin{array}{l}\text { Excited state } 2 \\
\mathrm{H} \rightarrow \mathrm{L}(70.62)\end{array}$ & 440.4 & 438 & 1.0304 & 2.8153 \\
\hline & $\begin{array}{c}\text { Excited state } 3 \\
\mathrm{H}-4 \rightarrow \mathrm{L}(15.0) \\
\mathrm{H}-3 \rightarrow \mathrm{L}(58.85) \\
\mathrm{H}-2 \rightarrow \mathrm{L}(21.8) \\
\mathrm{H} \rightarrow \mathrm{L}+1(26.2)\end{array}$ & 302.8 & 298 & 0.0071 & 4.0940 \\
\hline
\end{tabular}

H: HOMO; L: LUMO.

exothermic, and describe temperature effects on different thermodynamic properties [37].

3.6. Mulliken Population Analysis. The Mulliken atomic charges were computed by the determination of electron population of each atom. The atomic charges present a major role in the application of quantum mechanical calculations in a molecular system. These charges are observed to affect the properties like dipole moment, electronic parameters, polarizability, and refractivity [38]. The Mulliken charge distribution of the title compound in gas and other solvents (water, DMSO, acetonitrile, and ethanol) computed by employing 

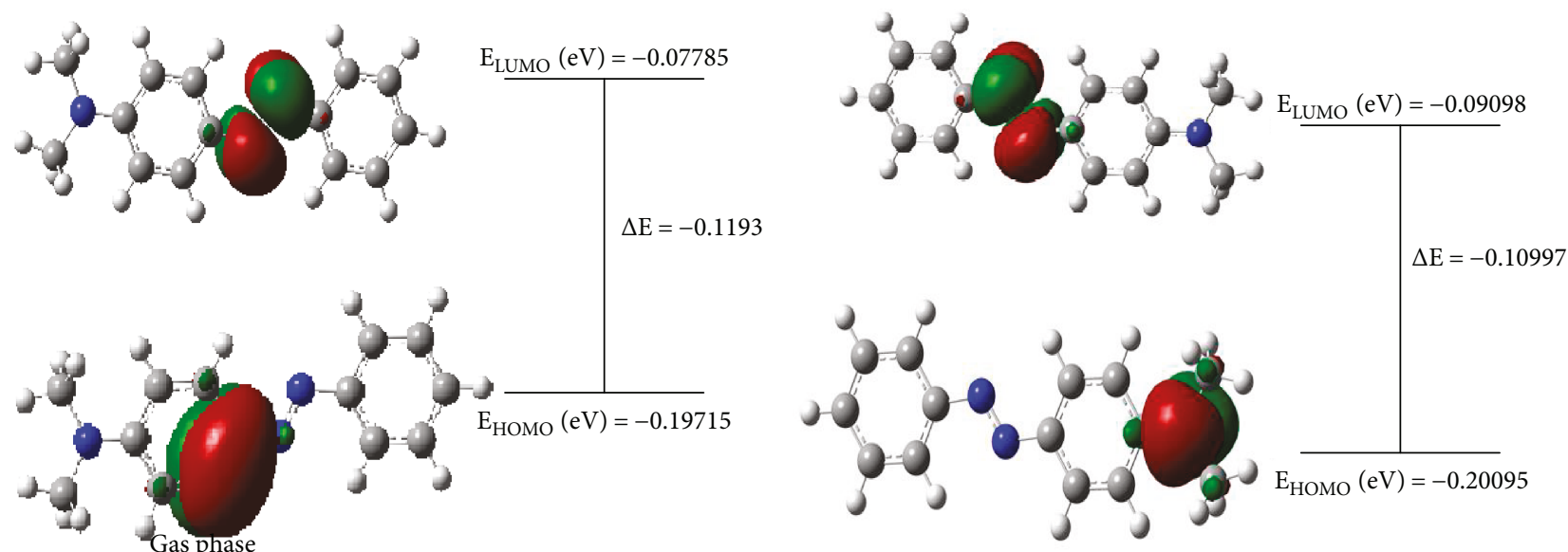

Water
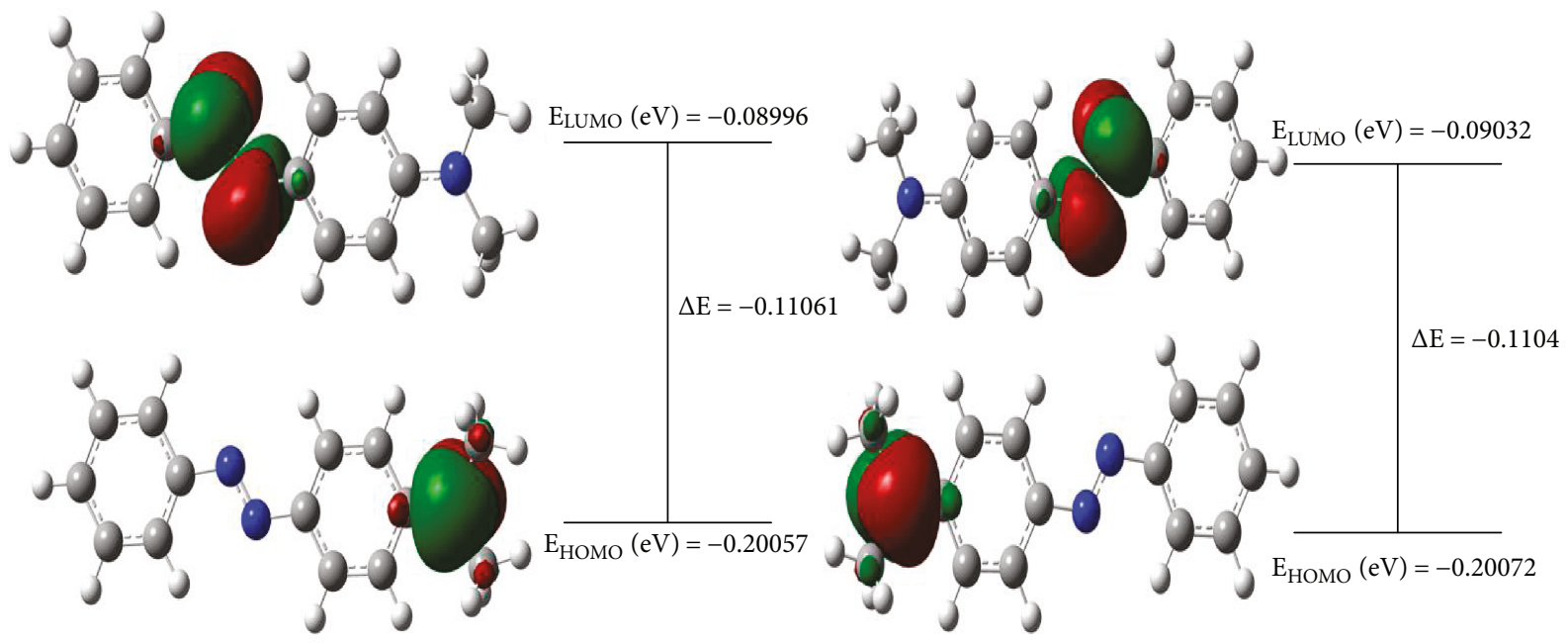

Ethanol

DMSO

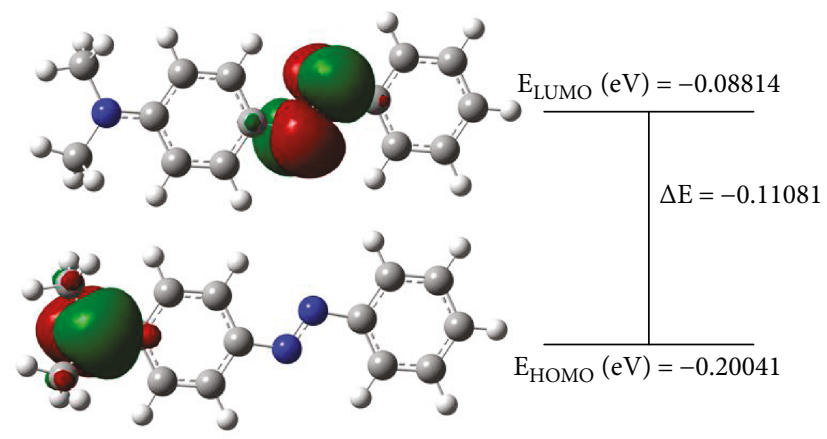

Acetonitrile

FIgure 5: The HOMO-LUMO orbitals and the energy gap of DMAB in gas and different solvent phases (DMSO, ethanol, acetonitrile, and water) computed at the DFT/B3LYP/6-311G++ level. 
TABLE 6: Energy values along with some thermodynamic corrections at DFT/B3LYP/6-311G++ in different phases.

\begin{tabular}{|c|c|c|c|c|c|}
\hline Properties & Gas & Water & DMSO & Acetonitrile & Ethanol \\
\hline $\mathrm{E}_{\text {HOMO }}(\mathrm{eV})$ & -0.19715 & -0.20095 & -0.20072 & -0.20041 & -0.20057 \\
\hline $\mathrm{E}_{\text {LUMO }}(\mathrm{eV})$ & -0.07785 & -0.09098 & -0.09032 & -0.0896 & -0.08996 \\
\hline$\Delta \mathrm{E}(\mathrm{eV})$ & -0.1193 & -0.10997 & -0.1104 & -0.11081 & -0.11061 \\
\hline Zero-point correction & 0.266224 & 0.264403 & 0.264484 & 0.264581 & 0.264561 \\
\hline $\mathrm{E}_{\text {corr }}$ & 0.281187 & 0.279508 & 0.279587 & 0.279678 & 0.279646 \\
\hline $\mathrm{H}_{\text {corr }}$ & 0.282131 & 0.280453 & 0.280531 & 0.280622 & 0.28059 \\
\hline $\mathrm{G}_{\text {corr }}$ & 0.222618 & 0.218992 & 0.219721 & 0.219767 & 0.220029 \\
\hline $\mathrm{E}_{\text {electronic }}+\mathrm{E}_{0}$ & -706.3033 & -706.3209 & -706.3199 & -706.31906 & -706.3195 \\
\hline $\mathrm{E}_{\text {electronic }}+\mathrm{E}_{\text {thermal }}$ & 706.2883 & -706.3058 & -706.3048 & -706.3039 & -706.3044 \\
\hline $\mathrm{H}_{\text {electronic }}+\mathrm{H}_{\text {thermal }}$ & -706.2874 & -706.3048 & -706.3038 & -706.3030 & -706.3034 \\
\hline $\mathrm{G}_{\text {electronic }}+\mathrm{G}_{\text {thermal }}$ & -706.3469 & -706.3663 & -706.3646 & -706.3638 & -706.3640 \\
\hline
\end{tabular}

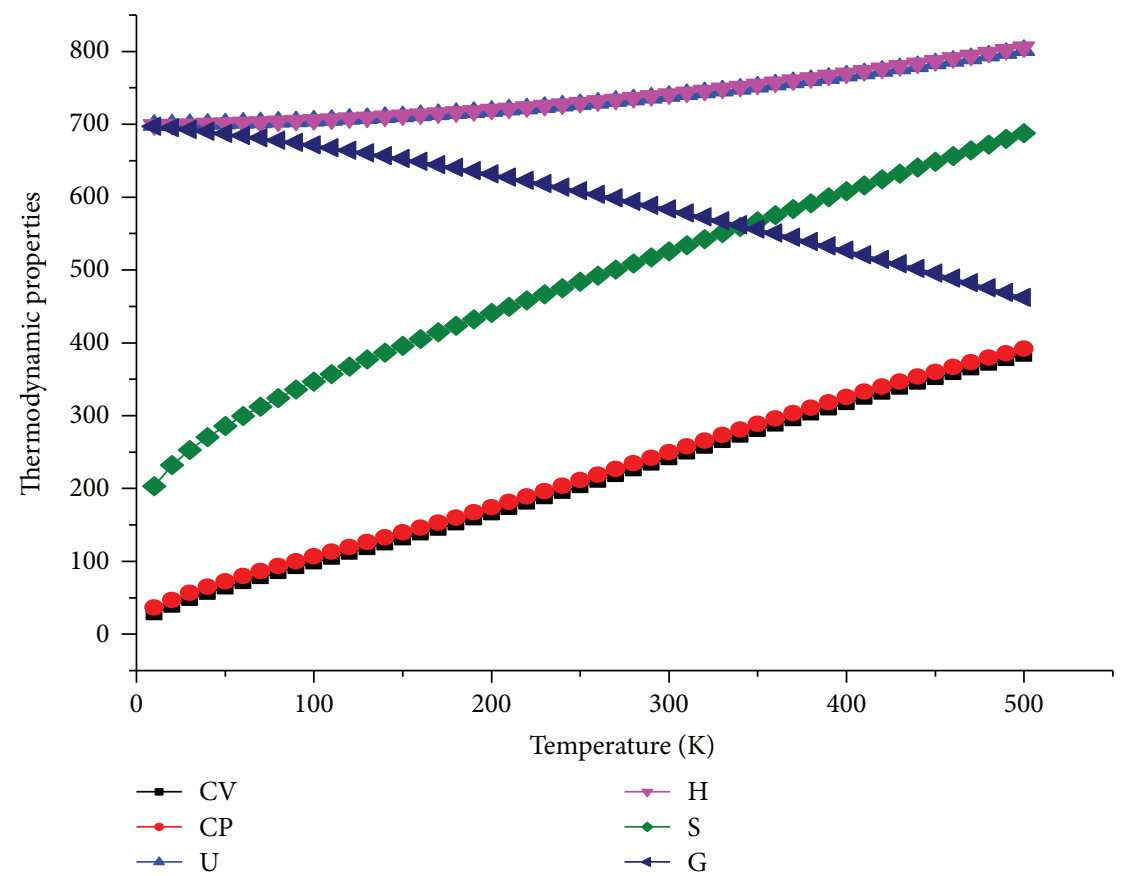

FIGURE 6: Thermodynamic parameters calculated by a Moltran program for DMAB in the gas phase in temperature range of $0-500 \mathrm{~K}$.

the DFT/B3LYP/6-311G++ level is presented in Table 7. Figure 7 exhibits the comparison of MPA with NPA. Natural population analysis better describes the electronic charge distribution over the system, and numerical stability is also higher as compared to MPA. As charge distribution seems to be method sensitive that is why we have made its comparison within three types of analyses. The table represents that all hydrogen atoms have positive charges. The carbon atoms in the ring carry both positive and negative charges. The substituted nitrogen has negative charge [39].

3.7. Molecular Electrostatic Potential (MESP). The main objective of molecular electrostatic potential calculations is to analyze electron density distribution over the molecule.
It is much useful for the prediction of reactivity of the molecule towards nucleophilic and electrophilic attacks [40]. It also guesses which types of intermolecular interactions are possible [41]. In the case of electrophilic attack in the molecule, it will preferably go to the most negative portion of the molecule; that is, the site with most dominant electron effect.

Figure 8 shows the molecular electrostatic potential map of DMAB created on the isodensity surface. The portion with red color is representative of negative charge with higher electron density, while the region in blue is electropositive with lower electron density. The figure depicts that maximum electron density is concentrated near nitrogen atom so this will be the best site for electrophilic attack. The 
TABLE 7: Mulliken charge distribution at the DFT/B3LYP level using the 6-311G++ basis set in the gas phase and other solvents.

\begin{tabular}{|c|c|c|c|c|c|}
\hline Atom & Gas & Water & DMSO & Acetonitrile & Ethanol \\
\hline $\mathrm{N}_{1}$ & -0.011175 & -0.107646 & -0.101575 & -0.096732 & -0.099325 \\
\hline $\mathrm{N}_{2}$ & -0.11088 & -0.191683 & -0.182724 & -0.17922 & -0.183646 \\
\hline $\mathrm{C}_{3}$ & -0.964584 & -0.865943 & -0.868616 & -0.867736 & -0.87238 \\
\hline $\mathrm{C}_{4}$ & -0.27397 & -0.40611 & -0.388743 & -0.386387 & -0.397171 \\
\hline $\mathrm{C}_{5}$ & -0.287814 & -0.343004 & -0.332364 & -0.332814 & -0.332595 \\
\hline $\mathrm{C}_{6}$ & -0.518278 & -0.495109 & -0.502062 & -0.508908 & -0.488843 \\
\hline $\mathrm{C}_{7}$ & 0.11618 & 0.06111 & 0.049367 & 0.05579 & 0.05428 \\
\hline $\mathrm{C}_{8}$ & 1.348058 & 1.415753 & 1.406569 & 1.408037 & 1.405625 \\
\hline $\mathrm{H}_{9}$ & 0.187111 & 0.223492 & 0.22255 & 0.220635 & 0.221356 \\
\hline $\mathrm{H}_{10}$ & 0.169508 & 0.209767 & 0.206062 & 0.204089 & 0.20516 \\
\hline $\mathrm{H}_{11}$ & 0.211913 & 0.233189 & 0.232393 & 0.23133 & 0.23176 \\
\hline $\mathrm{H}_{12}$ & 0.169214 & 0.209464 & 0.206016 & 0.203955 & 0.204996 \\
\hline $\mathrm{N}_{13}$ & -0.364749 & -0.380862 & -0.380324 & -0.37992 & -0.379794 \\
\hline $\mathrm{C}_{14}$ & -0.433692 & -0.44572 & -0.444993 & -0.444278 & -0.44475 \\
\hline $\mathrm{C}_{15}$ & -0.419182 & -0.431891 & -0.431128 & -0.430464 & -0.430771 \\
\hline $\mathrm{H}_{16}$ & 0.184567 & 0.205745 & 0.205045 & 0.203986 & 0.204382 \\
\hline $\mathrm{H}_{17}$ & 0.210973 & 0.221345 & 0.220623 & 0.220464 & 0.220358 \\
\hline $\mathrm{H}_{18}$ & 0.210973 & 0.221248 & 0.221304 & 0.220473 & 0.221016 \\
\hline $\mathrm{H}_{19}$ & 0.184855 & 0.206085 & 0.205439 & 0.204384 & 0.204747 \\
\hline $\mathrm{H}_{20}$ & 0.211592 & 0.221917 & 0.220925 & 0.221056 & 0.220658 \\
\hline $\mathrm{H}_{21}$ & 0.211592 & 0.22175 & 0.222065 & 0.221025 & 0.22178 \\
\hline $\mathrm{C}_{22}$ & -0.838681 & -0.725112 & -0.723776 & -0.729944 & -0.735159 \\
\hline $\mathrm{C}_{23}$ & 0.263727 & 0.130953 & 0.142923 & 0.149272 & 0.144443 \\
\hline $\mathrm{C}_{24}$ & -0.289609 & -0.320759 & -0.321584 & -0.319567 & -0.320392 \\
\hline $\mathrm{C}_{25}$ & -0.040794 & -0.082415 & -0.081129 & -0.079718 & -0.079108 \\
\hline $\mathrm{C}_{26}$ & -0.194248 & -0.27099 & -0.269817 & -0.261934 & -0.265361 \\
\hline $\mathrm{C}_{27}$ & 0.146422 & 0.180936 & 0.167236 & 0.162434 & 0.175074 \\
\hline $\mathrm{H}_{28}$ & 0.186962 & 0.22148 & 0.220612 & 0.218907 & 0.219478 \\
\hline $\mathrm{H}_{29}$ & 0.174802 & 0.2176 & 0.216708 & 0.21444 & 0.215154 \\
\hline $\mathrm{H}_{30}$ & 0.172003 & 0.215327 & 0.214442 & 0.21214 & 0.21287 \\
\hline $\mathrm{H}_{31}$ & 0.175449 & 0.21762 & 0.216701 & 0.214474 & 0.215188 \\
\hline $\mathrm{H}_{32}$ & 0.211756 & 0.232464 & 0.231855 & 0.230731 & 0.230971 \\
\hline
\end{tabular}

positive electrostatic potential is concentrated near carbon atoms so it will be a good site for attack of nucleophile.

\section{Conclusion}

This manuscript presents thorough analysis of the geometrical parameters, Mulliken population analysis in comparison with natural population analysis electronic absorption spectra, NBO analyses, HOMO-LUMO energy orbitals, MESP isodensity surface computation and the vibrational spectra of the title compound, and DMAB in the gas phase as well as in four different solvents (water, DMSO, acetonitrile, and ethanol). This compound was investigated by employing the DFT/B3LYP/6-311G++ method. All the significant vibrations observed in the experimental spectra (FT-IR/FTRaman) and computed frequency (IR/Raman) spectra of the compound are assigned to the various modes of vibration, and most of the modes have expected wavenumber range. Small discrepancies in vibrational wavenumbers could be due to different media in the recorded and computed spectra. The complete vibrational assignment is made on the basis of potential energy distribution (PED). Both vibrational spectra (IR/Raman) and electronic spectra help to predict diverse properties of the title molecule. The excellent agreement found in the observed and calculated vibrational spectra discloses the advantages of a higher basis set for quantum chemical calculation. NBO analysis provides an efficient method to explain accurate calculations into chemical insights. Experimental and calculated values of most of the bond lengths and bond angles of the title compound are found very close. The thermodynamic parameters were studied to explain the thermal behavior of the title compound. Mulliken charge investigation provides insight into chemical reactivity of our studied compound. 


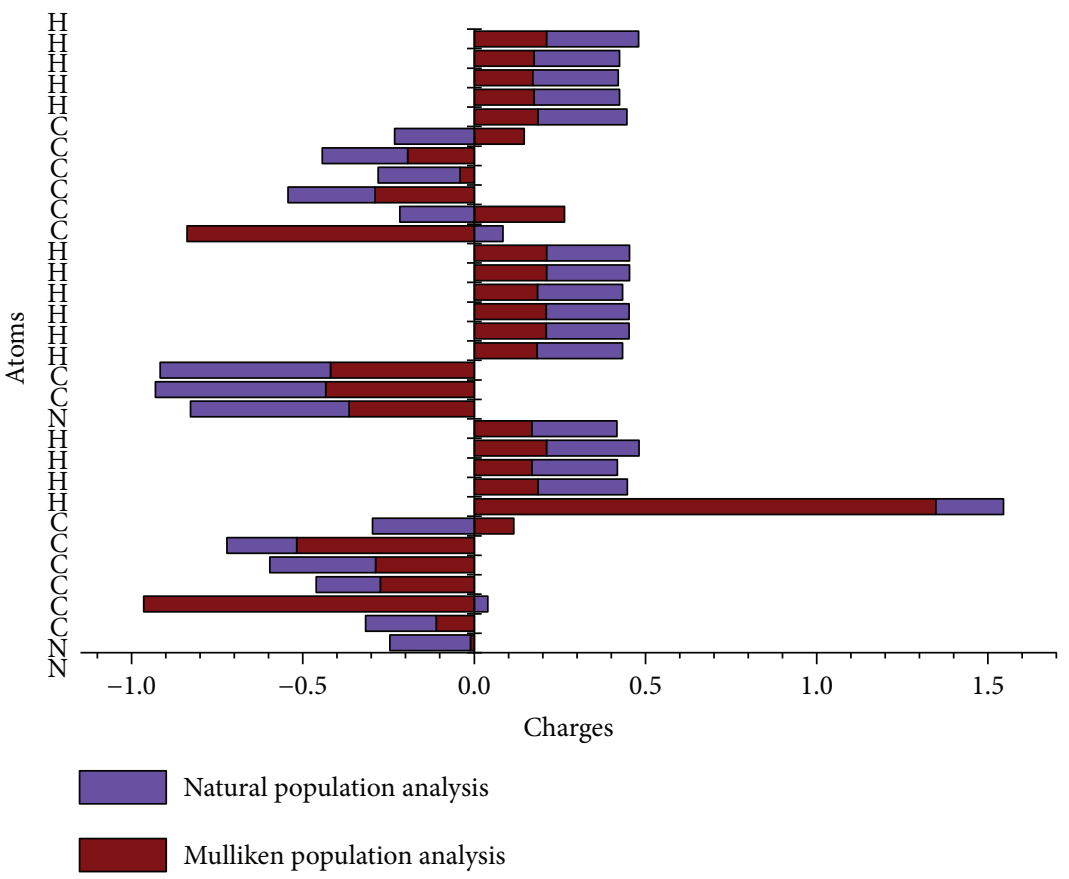

Figure 7: The population distribution graph of DMAB at DFT/B3LYP/6-311G++; comparison of electrostatic charge distribution, natural population analysis, and Mulliken charge distribution in the gas phase.

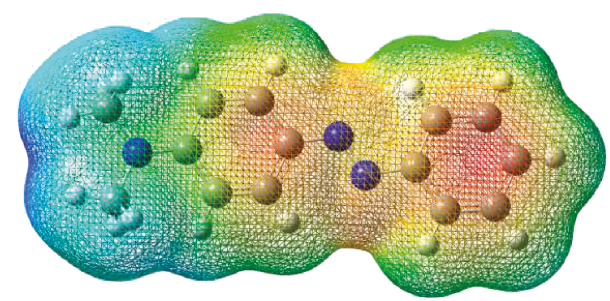

Figure 8: Molecular electrostatic potential mapped on the isodensity surface for DMAB calculated by DFT/B3LYP/6-311G++.

\section{Conflicts of Interest}

The authors declare that they have no conflicts of interest.

\section{Acknowledgments}

Authors are highly thankful to Higher Education Commission (HEC), Pakistan for the financial support for the current study (NRPU-2016-17/Project no. 5613).

\section{References}

[1] A. Alimmari, B. Božić, D. Mijin, A. Marinković, N. Valentić, and G. Ušćumlić, "Synthesis, structure and solvatochromic properties of some novel 5-arylazo-6-hydroxy-4-(4-methoxyphenyl)-3-cyano-2-pyridone dyes: hydrazone-azo tautomeric analysis," Arabian Journal of Chemistry, vol. 8, no. 2, pp. 269-278, 2015.

[2] T. Kitagawa, T. Yokochi, and H. Sugano, " $\alpha$-Fetoprotein and hepatocarcinogenesis in rats fed $3^{\prime}$-methyl-4-(dimethylamino)azobenzene or n-2-fluorenylacetamide," International Journal of Cancer, vol. 10, no. 2, pp. 368-381, 1972.
[3] M. Nomura, M. Nakachiyama, T. Hida et al., "Gomisin A, a lignan component of Schizandora fruits, inhibits development of preneoplastic lesions in rat liver by $3^{\prime}$-methyl-4-dimethylamino-azobenzene," Cancer Letters, vol. 76, no. 1, pp. 11-18, 1994.

[4] T. Eren, M. Kose, K. Sayin, V. McKee, and M. Kurtoglu, "A novel azo-aldehyde and its $\mathrm{Ni}$ (II) chelate; synthesis, characterization, crystal structure and computational studies of 2-hydroxy-5$\{(E)$-[4-(propan-2-yl)phenyl]diazenyl\}benzaldehyde," Journal of Molecular Structure, vol. 1065-1066, pp. 191-198, 2014.

[5] J. P. Graham, M. A. Rauf, S. Hisaindee, and M. Nawaz, "Experimental and theoretical study of the spectral behavior of Trypan Blue in various solvents," Journal of Molecular Structure, vol. 1040, pp. 1-8, 2013.

[6] B. Hu, G. Wang, W. You, W. Huang, and X.-Z. You, “Azohydrazone tautomerism by in situ $\mathrm{Cu}^{\mathrm{II}}$ ion catalysis and complexation with the $\mathrm{H}_{2} \mathrm{O}_{2}$ oxidant of C.I. Disperse Yellow 79," Dyes and Pigments, vol. 91, no. 2, pp. 105-111, 2011.

[7] B. Babür, N. Seferoğlu, E. Aktan, T. Hökelek, E. Şahin, and Z. Seferoğlu, "Phenylazoindole dyes 3: determination of azohydrazone tautomers of new phenylazoindole dyes in solution and solid state," Journal of Molecular Structure, vol. 1081, pp. 175-181, 2015.

[8] Ç. Albayrak, M. Odabaşoğlu, A. Özek, and O. Büyükgüngör, "Synthesis, spectroscopic characterizations and quantum chemical computational studies of $(Z)-4-[(E)$-(4-fluorophenyl)diazenyl]-6-[(3-hydroxypropylamino)methylene]-2methoxycyclohexa-2,4-dienone," Spectrochimica Acta Part A: Molecular and Biomolecular Spectroscopy, vol. 85, no. 1, pp. 85-91, 2012.

[9] N. Siampiringue, G. Guyot, S. Monti, and P. Bortolus, “The cis $\rightarrow$ trans photoisomerization of azobenzene: an experimental re-examination," Journal of Photochemistry, vol. 37, no. 1, pp. 185-188, 1987. 
[10] H.-C. Kang, B. M. Lee, J. Yoon, and M. Yoon, "Synthesis and surface-active properties of new photosensitive surfactants containing the azobenzene group," Journal of Colloid and Interface Science, vol. 231, no. 2, pp. 255-264, 2000.

[11] H. Rau and D. Rötger, "Photochromic azobenzenes which are stable in the trans and cis forms," Molecular Crystals and Liquid Crystals Science and Technology. Section A. Molecular Crystals and Liquid Crystals, vol. 246, no. 1, pp. 143-146, 1994.

[12] H. Asanuma, D. Matsunaga, and M. Komiyama, "Clear-cut photo-regulation of the formation and dissociation of the DNA duplex by modified oligonucleotide involving multiple azobenzenes," Nucleic Acids Symposium Series, vol. 49, no. 1, pp. 35-36, 2005.

[13] G. Gauglitz and S. Hubig, "Azobenzene as a convenient actinometer: evaluation values for UV mercury lines and for the $\mathrm{N}_{2}$ laser line," Journal of Photochemistry, vol. 15, no. 3, pp. 255-257, 1981.

[14] D. Avc1, Ö. Tamer, and Y. Atalay, "Solvatochromic effect on UV-vis absorption and fluorescence emission spectra, secondand third-order nonlinear optical properties of dicyanovinylsubstituted thienylpyrroles: DFT and TDDFT study," Journal of Molecular Liquids, vol. 220, pp. 495-503, 2016.

[15] N. Ali, A. Mansha, S. Asim, A. F. Zahoor, S. Ghafoor, and M. U. Akbar, "A computational perspective of vibrational and electronic analysis of potential photosensitizer 2-chlorothioxanthone," Journal of Molecular Structure, vol. 1156, pp. 571-582, 2018.

[16] O. A. El-Gammal, "Mononuclear and binuclear complexes derived from hydrazone Schiff base NON donor ligand: synthesis, structure, theoretical and biological studies," Inorganica Chimica Acta, vol. 435, pp. 73-81, 2015.

[17] M. J. Frisch, G. W. Trucks, H. B. Schlegel et al., Gaussian 09, Revision B.01, Gaussian, Inc., Pittsburgh, PA, USA, 2009.

[18] S. Chibani, D. Jacquemin, and A. D. Laurent, "Modelling solvent effects on the absorption and emission spectra of constrained cyanines with both implicit and explicit QM/EFP models," Computational and Theoretical Chemistry, vol. 1040-1041, pp. 321-327, 2014.

[19] S. Shahab, H. A. Almodarresiyeh, R. Kumar, and M. Darroudi, "A study of molecular structure, UV, IR, and ${ }^{1} \mathrm{H}$ NMR spectra of a new dichroic dye on the basis of quinoline derivative," Journal of Molecular Structure, vol. 1088, pp. 105-110, 2015.

[20] S. K. Ignatov, Moltran v.2.5 - Program for Molecular Visualization and Thermodynamic Calculations, University of Nizhny Novgorod, 2004, http://www.unn.ru/chem/moltran.

[21] M. Elshakre and I. Sadiek, "A DFT study of the dissociation, ionization, and UV/visible spectra of methyl hypobromite," Computational and Theoretical Chemistry, vol. 1088, pp. 3243, 2016.

[22] D. Geldof, M. Tassi, R. Carleer et al., "Binding modes of phosphonic acid derivatives adsorbed on $\mathrm{TiO}_{2}$ surfaces: assignments of experimental IR and NMR spectra based on DFT/ PBC calculations," Surface Science, vol. 655, pp. 31-38, 2017.

[23] J. P. Merrick, D. Moran, and L. Radom, "An evaluation of harmonic vibrational frequency scale factors," The Journal of Physical Chemistry A, vol. 111, no. 45, pp. 11683-11700, 2007.

[24] R. Singh and R. A. Yadav, "Raman and IR studies and DFT calculations of the vibrational spectra of 2,4-dithiouracil and its cation and anion," Spectrochimica Acta Part A: Molecular and Biomolecular Spectroscopy, vol. 130, pp. 188-197, 2014.
[25] A. Kumar, A. K. Srivastava, S. Gangwar, N. Misra, A. Mondal, and G. Brahmachari, "Combined experimental (FT-IR, UV-visible spectra, NMR) and theoretical studies on the molecular structure, vibrational spectra, HOMO, LUMO, MESP surfaces, reactivity descriptor and molecular docking of Phomarin," Journal of Molecular Structure, vol. 1096, pp. 94-101, 2015.

[26] V. L. Furer, A. E. Vandyukov, J. P. Majoral, A. M. Caminade, and V. I. Kovalenko, "Structure, IR and Raman spectra of phosphotrihydrazide studied by DFT," Spectrochimica Acta Part A: Molecular and Biomolecular Spectroscopy, vol. 166, pp. 19-24, 2016.

[27] M. V. Castillo, R. A. Rudyk, L. Davies, and S. A. Brandán, "Analysis of the structure and the FT-IR and Raman spectra of 2-(4-nitrophenyl)-4H-3,1-benzoxazin-4-one. Comparisons with the chlorinated and methylated derivatives," Journal of Molecular Structure, vol. 1140, pp. 2-11, 2017.

[28] V. L. Furer, L. I. Potapova, and V. I. Kovalenko, "DFT study of hydrogen bonding and IR spectra of calix[6]arene," Journal of Molecular Structure, vol. 1128, pp. 439-447, 2017.

[29] S. Tarchouna, I. Chaabane, and A. B. Rahaiem, "FT-IR and Raman spectra and vibrational investigation of bis (4-acetylanilinium) hexachlorostannate using DFT (B3LYP) calculation," Physica E: Low-dimensional Systems and Nanostructures, vol. 83, pp. 186-194, 2016.

[30] S. Kaviani, M. Izadyar, and M. R. Housaindokht, "Solvent and spin state effects on molecular structure, IR spectra, binding energies and quantum chemical reactivity indices of deferiprone-ferric complex: DFT study," Polyhedron, vol. 117, pp. 623-627, 2016.

[31] A. Veeraiah, "FT-IR, FT-Raman, UV/Vis spectra and fluorescence imaging studies on 2-(bromoacetyl)benzo(b)furan by $a b$ initio DFT calculations," Spectrochimica Acta Part A: Molecular and Biomolecular Spectroscopy, vol. 147, pp. 212$224,2015$.

[32] X.-H. Liu, Z.-X. Zhao, J. Wang, W. Zhang, and H.-X. Zhang, "Theoretical investigation on the photoswitchable secondorder nonlinear optical properties of a series of $\mathrm{B}\left(\mathrm{C}_{6} \mathrm{~F}_{5}\right)_{2}$-coordinated dithienylethene derivatives," Journal of Photochemistry and Photobiology A: Chemistry, vol. 335, pp. 155-164, 2017.

[33] J. Xu, L. Wang, G. Liang et al., "Conjugate spacer effect on molecular structures and absorption spectra of triphenylamine dyes for sensitized solar cells: density functional theory calculations," Spectrochimica Acta Part A: Molecular and Biomolecular Spectroscopy, vol. 78, no. 1, pp. 287-293, 2011.

[34] N. Yasarawan, K. Thipyapong, and V. Ruangpornvisuti, "Structures and conformations of acridinium mono- and polymethine cyanine dyes and their UV-Vis absorption spectra in protic solvents: a PCM/TD-DFT study," Journal of Molecular Structure, vol. 1006, no. 1-3, pp. 635-641, 2011.

[35] A. Mahmood, I. U. Khan, R. L. Longo, A. Irfan, and S. A. Shahzad, "Synthesis and structure of 1-benzyl-5-amino-1H-tetrazole in the solid state and in solution: combining X-ray diffraction, ${ }^{1} \mathrm{H}$ NMR, FT-IR, and UV-Vis spectra and DFT calculations," Comptes Rendus Chimie, vol. 18, no. 4, pp. 422-429, 2015.

[36] W. Zhu, T. Wei, X. Zhang, and H. Xiao, "Density functional theory study of structural, vibrational, and thermodynamic properties of crystalline 2,4-dinitrophenol, 2,4-dinitroresorcinol, and 4,6-dinitroresorcinol," Journal of Molecular Structure: THEOCHEM, vol. 895, no. 1-3, pp. 131-137, 2009. 
[37] A. A. El-Bindary, G. G. Mohamed, A. Z. El-Sonbati et al., "Geometrical structure, potentiometric, molecular docking and thermodynamic studies of azo dye ligand and its metal complexes," Journal of Molecular Liquids, vol. 218, pp. 138-149, 2016.

[38] R. Hussain, A. I. Hussain, S. A. S. Chatha, A. Mansha, and K. Ayub, "Density functional theory study of geometric and electronic properties of full range of bimetallic $\mathrm{Ag}_{\mathrm{n}} \mathrm{Y}_{\mathrm{m}}$ $(\mathrm{n}+\mathrm{m}=10)$ clusters," Journal of Alloys and Compounds, vol. 705, pp. 232-246, 2017.

[39] M. Kumru, V. Küçük, M. Kocademir, H. M. Alfanda, A. Altun, and L. Sar1, "Experimental and theoretical studies on IR, Raman, and UV-Vis spectra of quinoline-7-carboxaldehyde," Spectrochimica Acta Part A: Molecular and Biomolecular Spectroscopy, vol. 134, pp. 81-89, 2015.

[40] P. Sjoberg and P. Politzer, "Use of the electrostatic potential at the molecular surface to interpret and predict nucleophilic processes," The Journal of Physical Chemistry, vol. 94, no. 10, pp. 3959-3961, 1990.

[41] J. S. Murray and P. Politzer, "The electrostatic potential: an overview," Wiley Interdisciplinary Reviews: Computational Molecular Science, vol. 1, no. 2, pp. 153-163, 2011. 

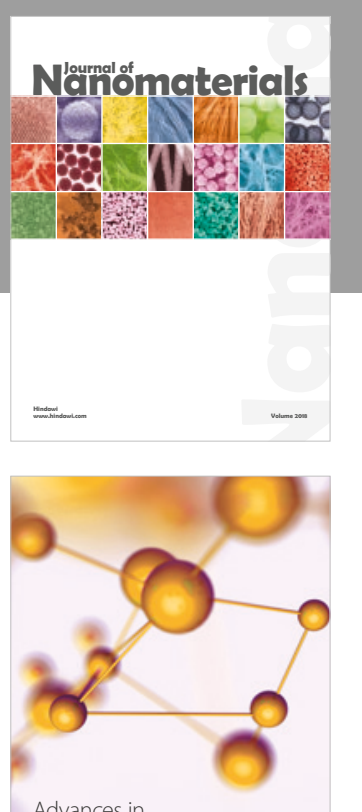

Physical Chemistry
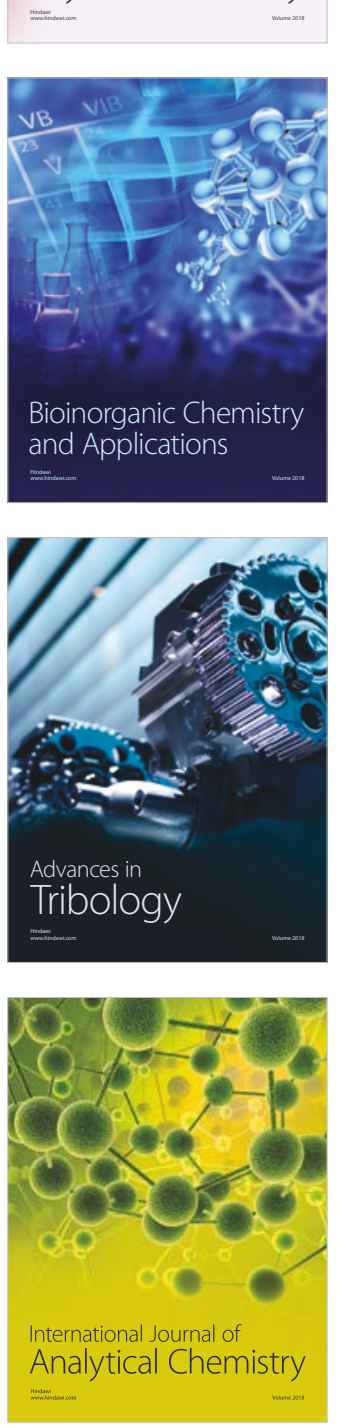

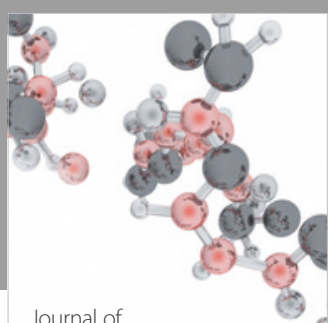

Analytical Methods

in Chemistry

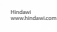

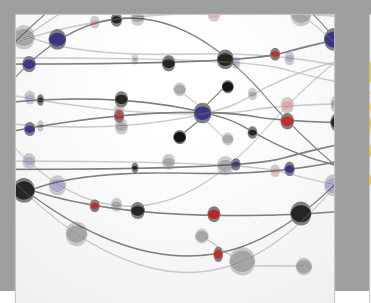

The Scientific World Journal

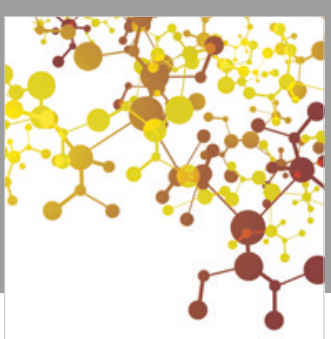

Journal of

Applied Chemistry
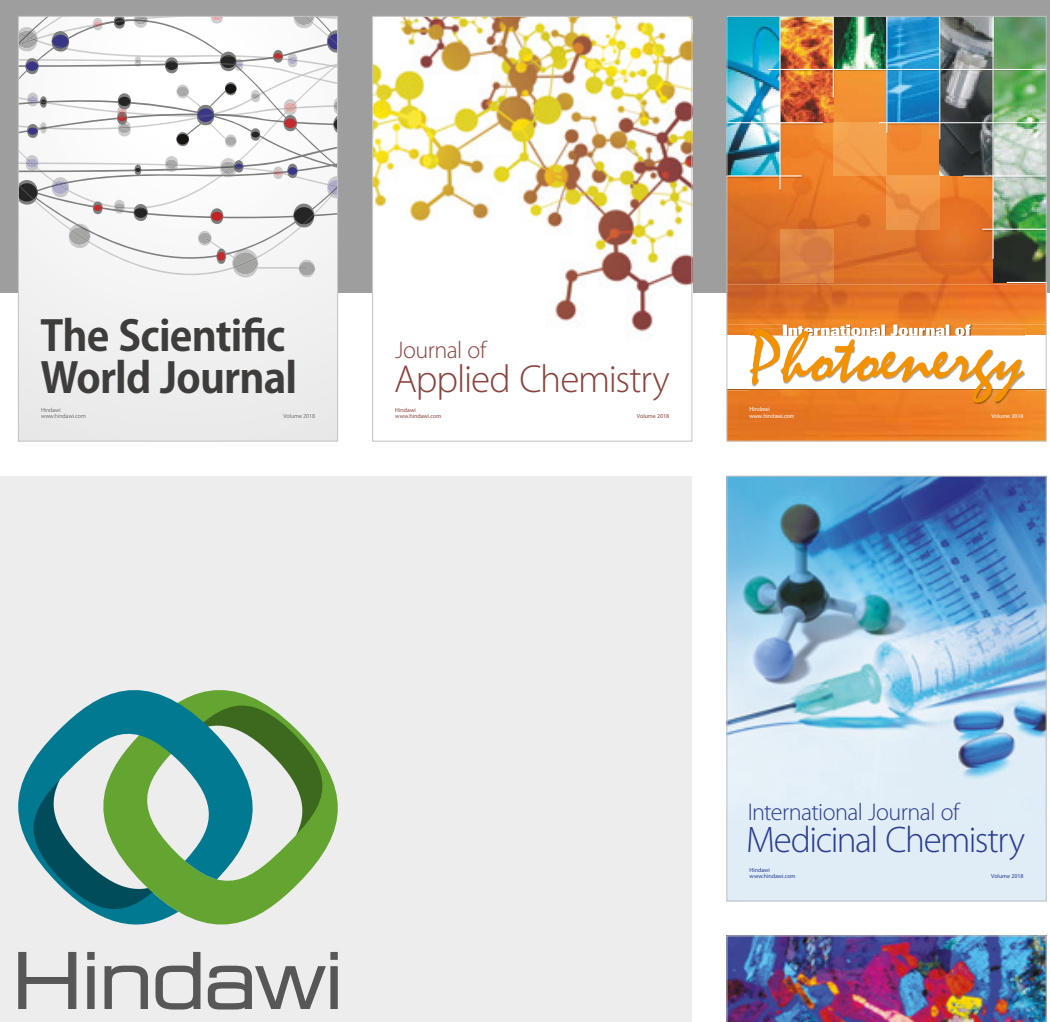

Submit your manuscripts at

www.hindawi.com
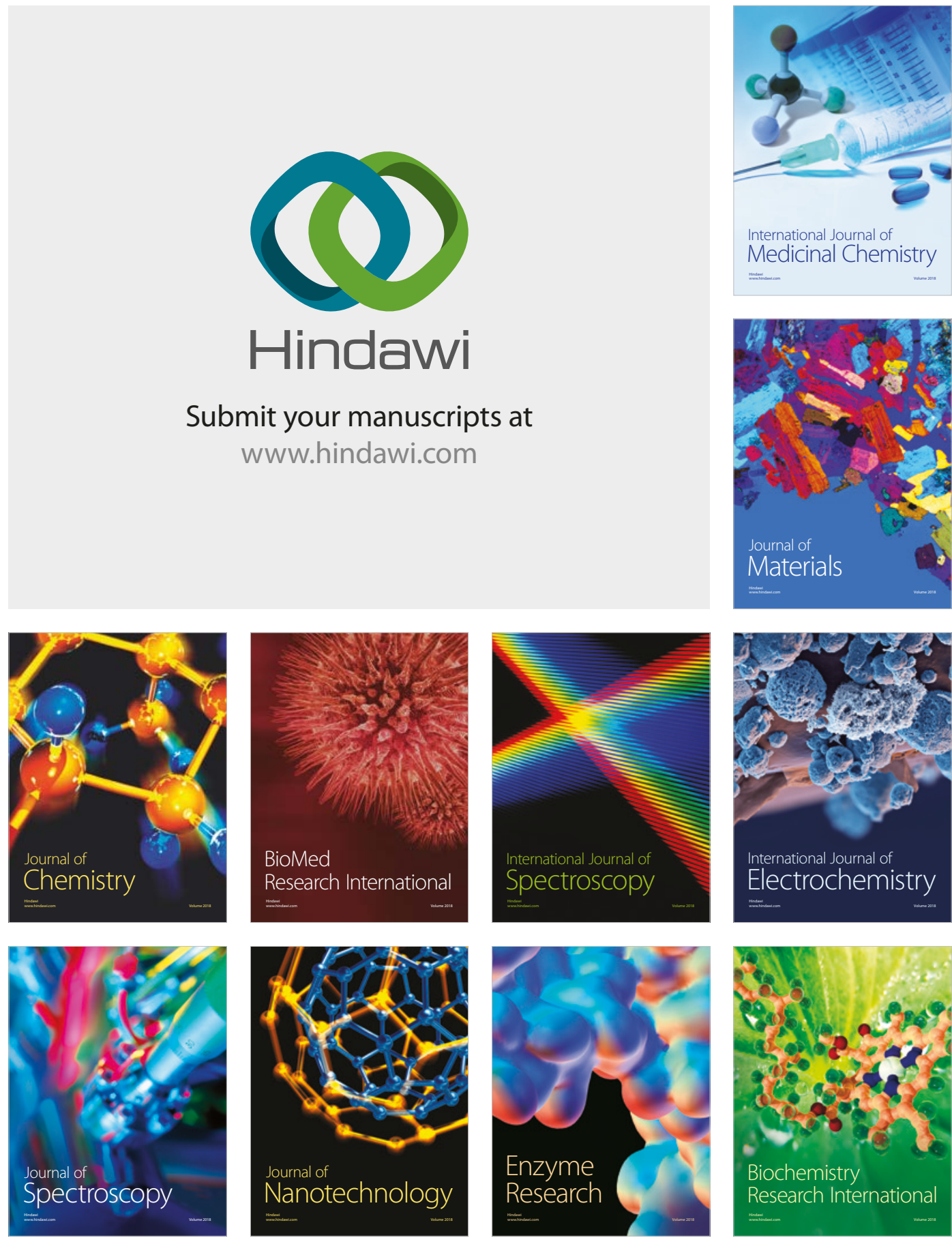
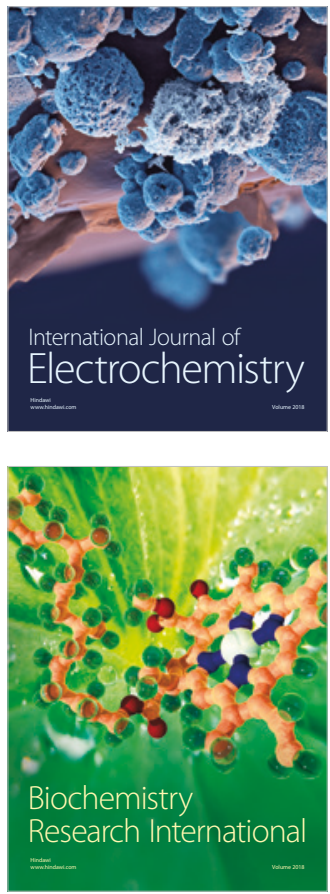